\title{
فاعلية أنشطة مقترحة في ضوي مبادئ منتسوري لتنمية الوعي الوقائي بالعلوم لدى التلاميذ المعاقين عقلياً بالمرحلة الابتدائية
}

\section{منى محمدابراهيم مخمدصالح}

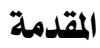

لتقديم الخدمات المناسبة لنالك الفئة؛ لذلك فان

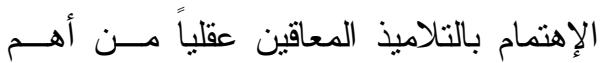

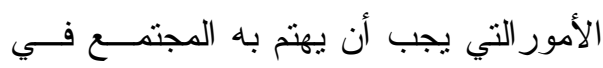

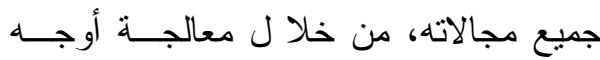

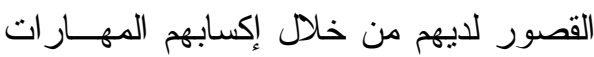
التي تمكنهم من التكيف مع البيئة المحيطـــة بهק.

وتتمية الوعي الوقـائي يُعـــد مــن

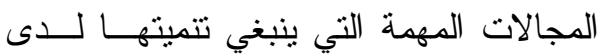

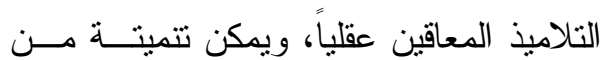
خلال جميع المو اد الدر اسية وخاصــة مــادة العلوم؛ فيتعلمون كيفية حماية أنفسهم ومسن الأذى و الأخطار ، و إتاحة الفرصة لممارســـة السلوكيات و العادات السليمة اتجاه أنفسهم. ولما كانت التزبية تهدف بوجه عـام

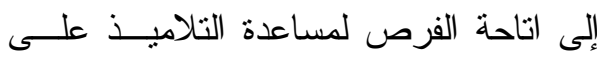

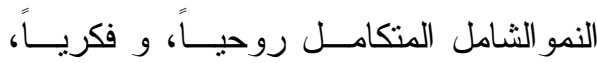

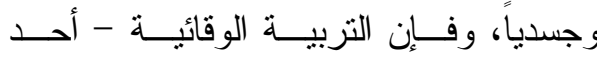
مجالات التربية - ضرورة ملحة في وقتنــان

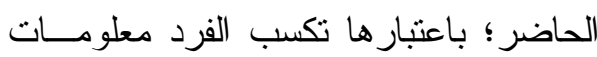
ومهار ات تساعده في التغلب على العديد من مــشكلات البيئـــة، و الــــــة، و التغذيــــة،
يشهـ العصر الحالي تطور ات علميــة

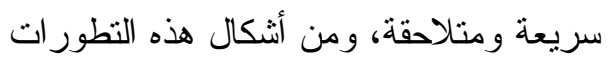

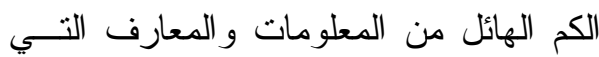

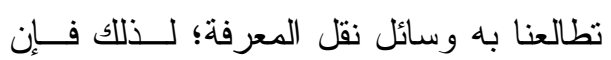
الإنسان أصبح مطالب بأن يكون لديه قــدر

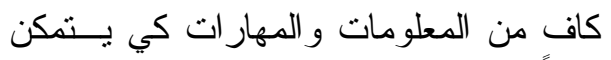
من مو اكبة تلك التطور ات التي نز ايدت معها

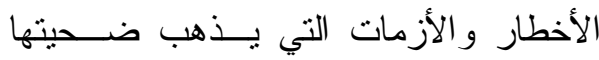
مئات الأرواح في شتى أنحاء العالم، ويتمثل

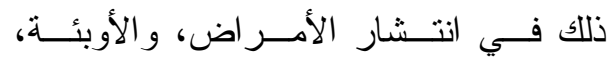

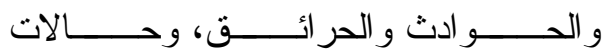

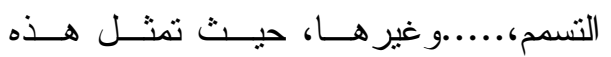
الأخطار تهديداً لحياة الإنسان، وتز اد خطورة

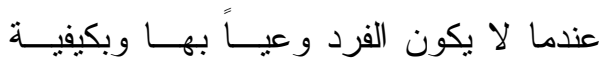

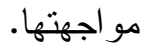
وتعد مشكلة الإعاقـــة العقليــة مــن المشكلات القديمة التى يهتم بها علماء النفس،

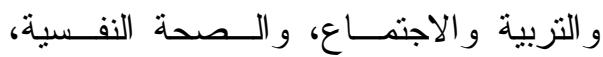
و الطب كونها ظاهرة معقدة الجو انب، وتعتبر

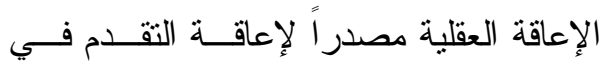

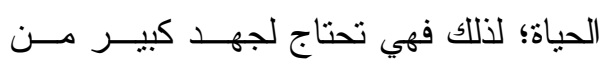
القائمين على تتشئة وتأهيل المعـاقين عقليـاً 
وقد أثنارت العديد من الدر اسات إلـى

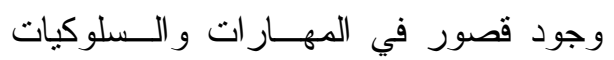

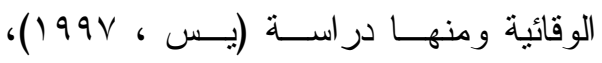

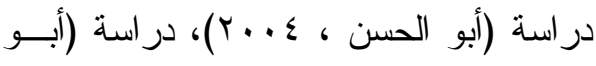

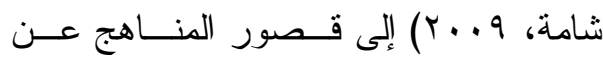

تحقيق أهداف التربية الصحية و وعدم تضمين

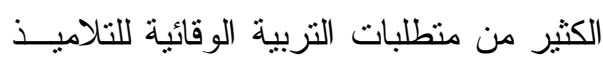

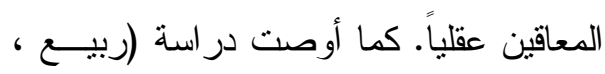

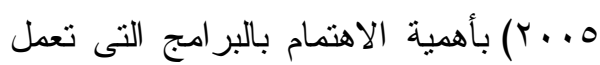

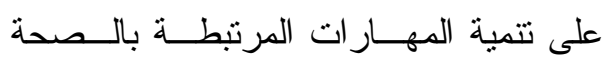

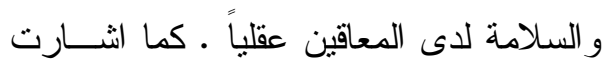

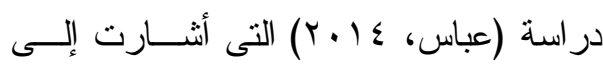

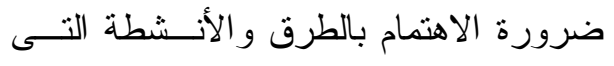

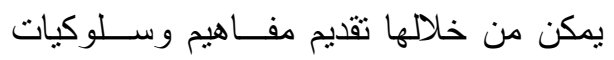
التربية الوقائية للتلاميذ المعاقين عقليا بحيث

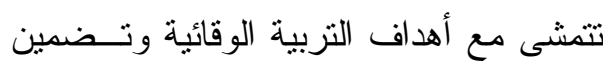

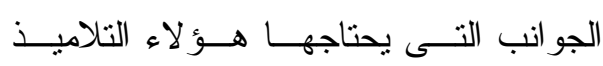

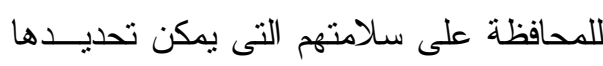

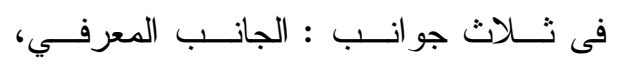

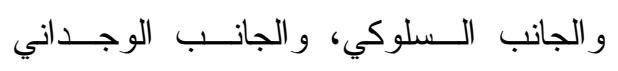

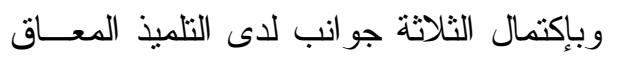

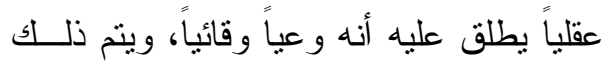
من خلال ممارسة الأنشطة التعليمية .

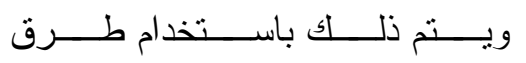
و واستراتيجيات تدريس تقوم على مبدأ أساسي

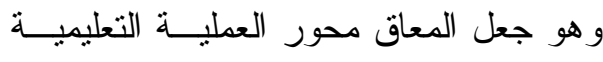
ويكون له دور نشط في عملية التعلم (السعيد

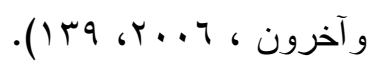

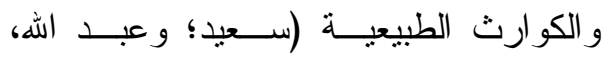
. (r. 9 6r...V

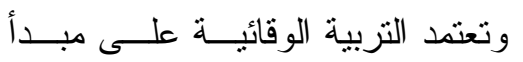

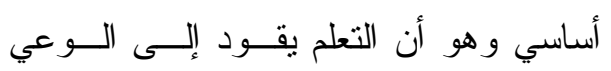

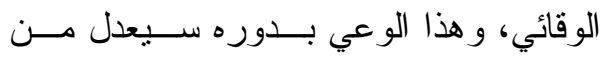

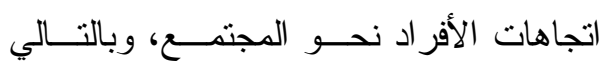
سلوكياتهم، و إكسابهم القــدرة علــى اتخــاذ

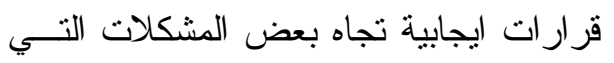

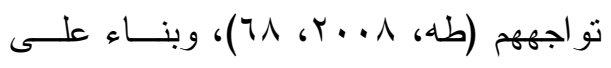

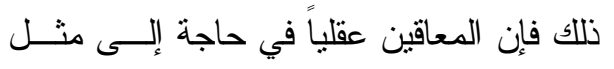

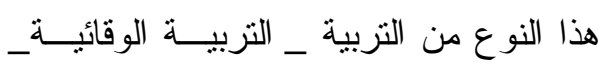

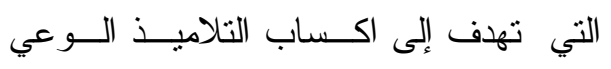
الوقائي تجاه عناصر المجتمع و مسـشكلاته

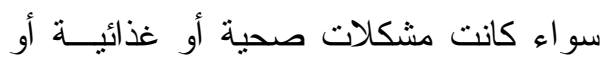
بيئية ، وكيفية التصرف في المو اقف بـشكل

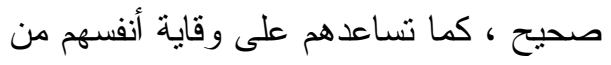
المخاطر أثناء تفاعلهم مع البيئة المحيطة بهم

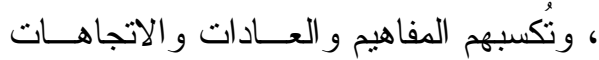
السلوكية المرغوب فيها.

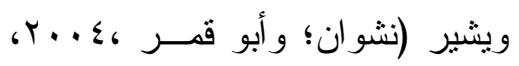
(VV المتعلم القائم على المعرفة والإحساس بأبعاد

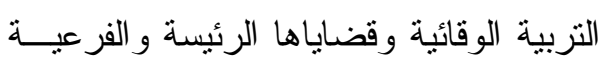
ويتضمن الوعي جانبين هما : جانب معرفي لئي

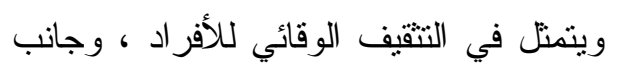

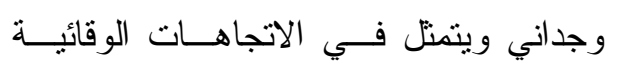
لـأفر اد 
إمكانية استخدام أنشطة منسوري فى تحقيــق العديد من أهداف تعليم الإعاقة العقلية.

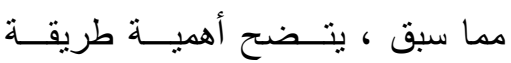

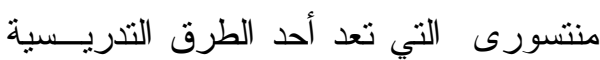
التى يمكن فى ضوئها تصميم أنشطة تمكـنـن

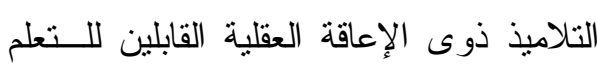
اكتساب المفاهيم و الـسلوكيات و الاتجاهــات الوقائية وهذة الأنشطة تكون مرتبطة بحيـاة التلميذ المعاق بشكل مباثر كما أنها تكـــون ضرورية للتكيف مع أنشطة حياته المختلفة .

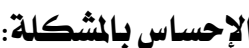

من خلال الزيار ات التى قامـــت بهــــا

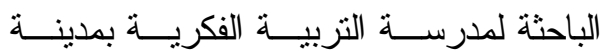

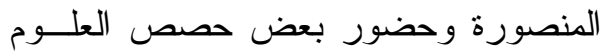
وفحص مناهج العلوم بتلك المدرسة لــوحظ

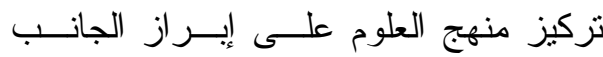
المعرفي من مفاهيم وحقائق بــصورة غيـر

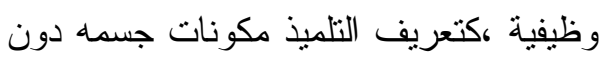
إيضاح لطريقة المحافظة على هذه المكونات

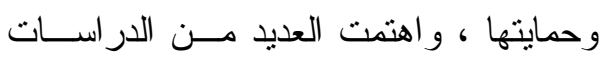

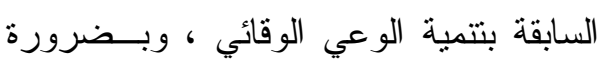

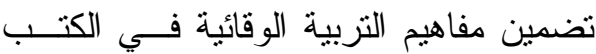

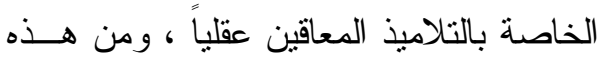

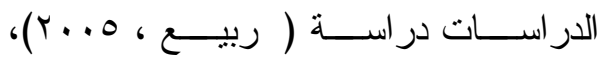

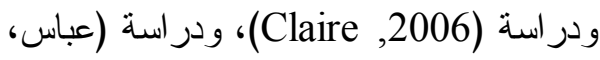

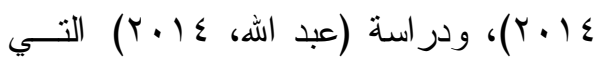
أوصت جميعها بأهمية الاهتمــام بالأنسشطة ولثة المعززة للوقاية و السلامة للمعاقين عقلياً.
وهذا يتفق مع طريقة منتسورى التي

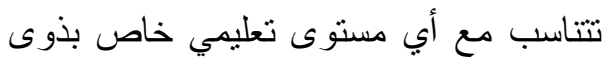
الاحتباجات الخاصة بصفة عامة و المعـاقين

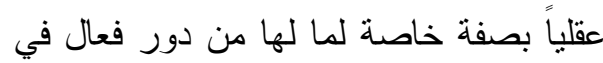

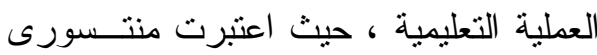
مشكلة الاعاقة العقلية مشكلة ثربويــة أكثــر

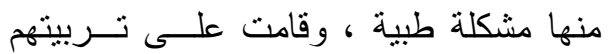

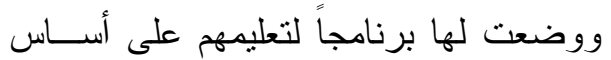
الربط بين خبــر اتهم المنزليــة و المدرســـية و إعطائهم فرصة التعبير عن رغباتهم وتعليم

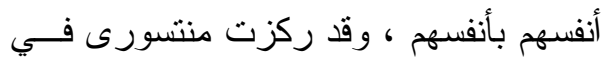

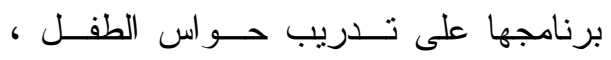
كتدريب حاسة اللمس و السمع و التـذوق و الابصـار، كما ركزت على تدريب الطفــل الاعتماد على نفسه.

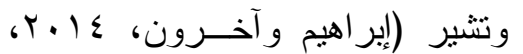

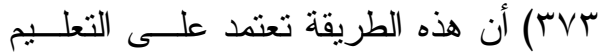
الفردى باستخدام التدريب الحسحركى بدرجة

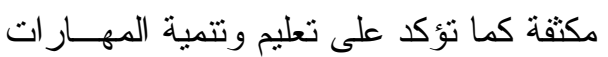
المنتو عة . وقد أثنارت العديد من الدراسات على هـ

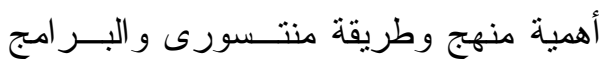
القائمة على إستخدام أنشطة منتسورى فـى منى تنمية جوانب متعددة لدى التلاميذ المعساقين

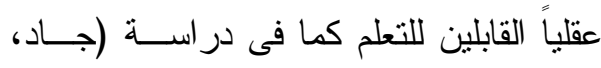

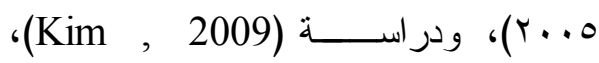

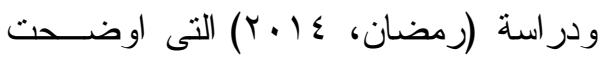


r. ما فعالية الأنشطة المقترحة فئ ضـــوء

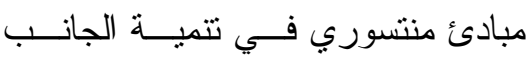

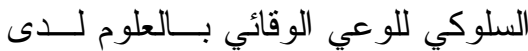

التلاميذ المعاقين عقليا القـابلين للــتعلم

$$
\text { بالمرحلة الإبتدائية؟ }
$$

r. ما فعالية الأنشطة المقترحة فئ ضـــوء

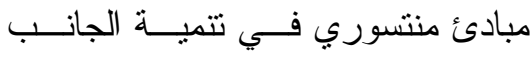

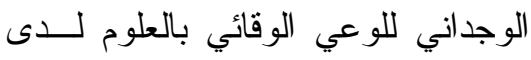

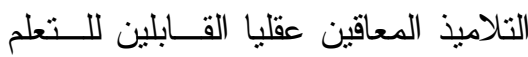

$$
\text { بالمرحلة الإبتدائية؟ }
$$

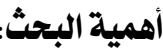

$$
\text { قد يفيد البحث الحالي فى : }
$$

1. تقديم أدو ات مضبوطة علمياً نتمثل فـي لـي

مقياس الوعى الوقائى ( بجو انبه الثثلاثة)

يمكن أن يُسهم فى الكثف عن الؤى مستوى

الوعى الوقائى لدى التلاميــذ المعــاقين

عقليا القابلين للتعلم فى مدارس التربيـــة

$$
\text { الفكرية. }
$$

r. توجيه أنظـــار القــائمين علــى تعلــيم

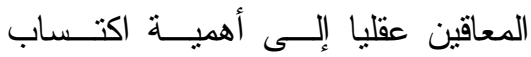

التلاميذ المعـاقين عقليــا الـسلوكيات

و المفاهيم الوقائية من أجل التكيف مــع

$$
\text { منطلبات الحياة. }
$$

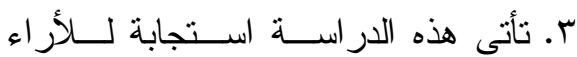

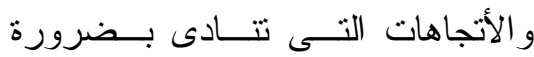

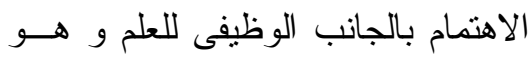

$$
\text { تأكيد للبعد الوقائى في مناهج العلوم. }
$$

كما لوحظ أن هناك قصور في طريقة

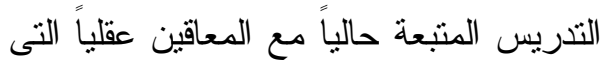

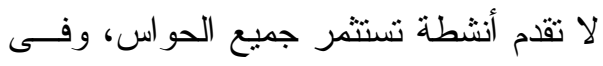

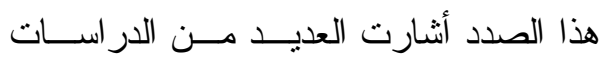
السابقة إلى أهمية طريقة منتسوري في تتمية المهار ات المعرفية والاجتماعية لدى التلاميذ

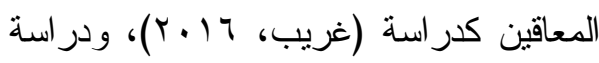

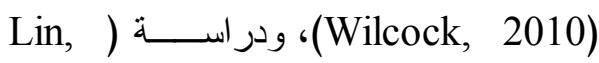

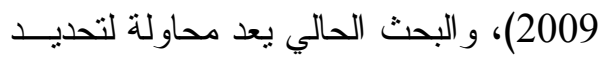

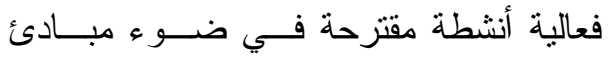

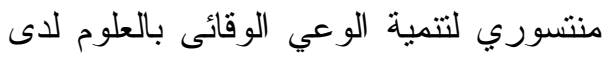

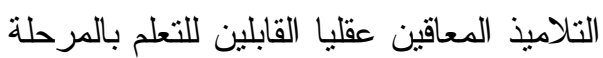
الإبتدائية.

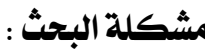

تم تحديد مشكلة البحث في السؤال الرئيس

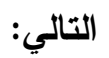
ما فعالية أنشطة مقترحة فـي ضـــوء

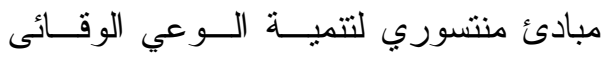
بالعلوم لدى التلاميذ المعاقين عقليا القـابلين

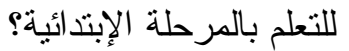

\section{وتفرع من السؤال الرئيس الأسئلة الآتية:}

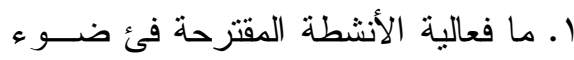
مبادئ منتسوري فــي تتميــة الجانــبـ فئس

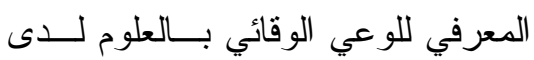

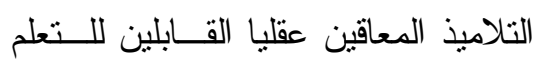

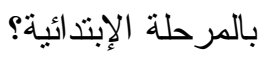




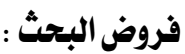

في ضوء أدبيات البحث مسن خــلال

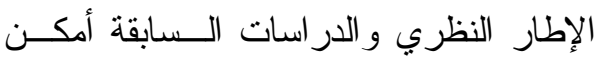

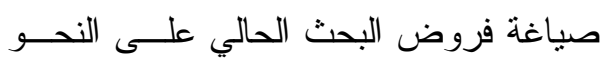

الآتي :

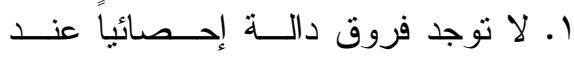

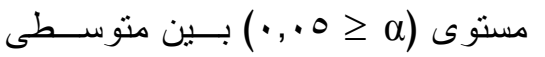

رتــب درجــات طـــلاب المجموعـــة

التجريبية و المجموعة الــضابطة فـى رئ

الجانب المعرفي لمقياس الوعي الوقائي بعدياً.

r. لاتوجد فروق دالة إحصائياً عند مستوى بعليا.

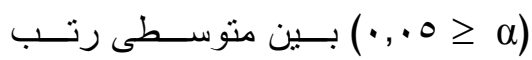

درجات طلاب المجموعـــة التجريبيـــة

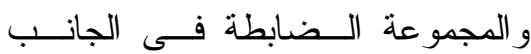

السلوكي لمقياس الوعي الوقائي بعدياً.

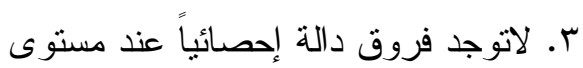

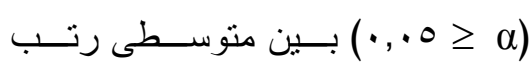

درجات طلاب المجموعــة التجريبيــة

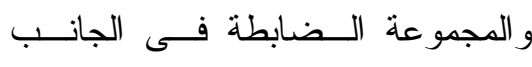

الوجداني لمقياس الوعي الوقائي بعدياً.

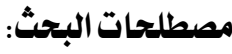

ا ـ طريقة منتسوري : تُعرف بأنها: طريقة

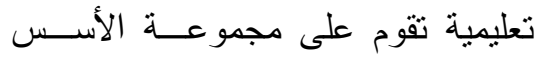

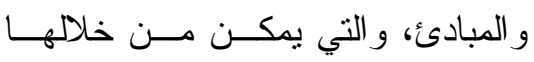

تصميم مجموعة من الأنسشة التشي ونسي

تساعد التلاميذ المعاقين عقلياً القـابلين

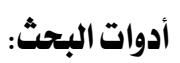

أولاً: مواد المعالجة التجريبية:

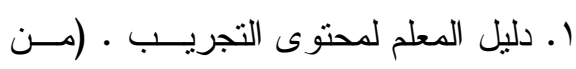

إعداد الباحثة)

r. دليل نشاط النلميذ. (من إعداد الباحثة)

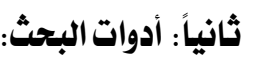

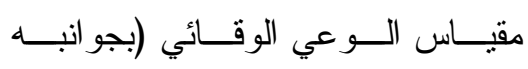

الثناثة). (من إعداد الباحثة)

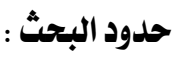

ا ـ حدود مكانية: اقتصر البحــث الحــالي

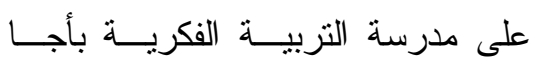

(لمجموعة التجريبية)، ومدرسة التربية

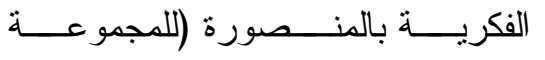

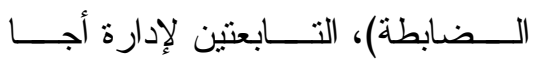

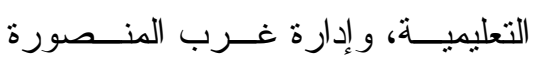

التعليمة بمحافظة الدقهلية.

r r حدود زمانية : تم تطبيق البحث الحالي لئه

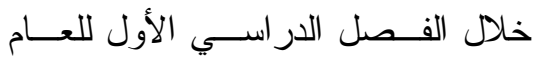

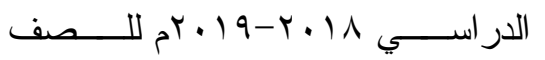

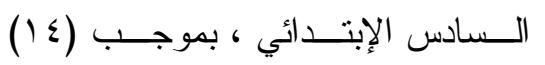

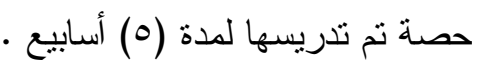

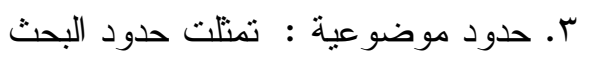

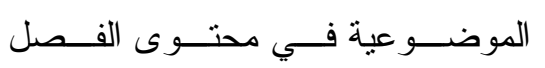

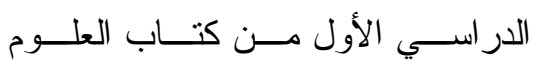

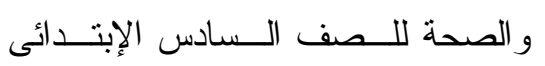

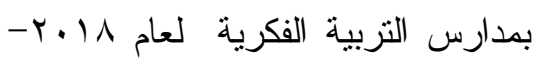


السلوك التكيفى وظهور ه فــى مر احـل

النمو المختلفة عند الفرد قبل سن (1) (1).

ع. المعاقون عقليـاً القــابلون للــتعلم :

يُعرف المعاقون عقلياً القابلون للــتعلم

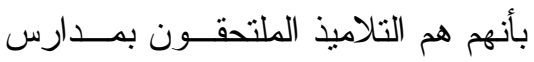

وفصول التربية الفكرية، وتتزاوح نسبة

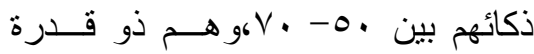

محدودة تسمح لهـم بالاسـتفادة مسن

البر امج التعليمية العادية ولكن بـصورة

بطيئة، فهم يحتــاجون إلــى أســاليب

وبر امج تعليمية خاصة، لإحداث تغيـر

في السلوك الاجتماعي ليصبح مقبـــولاً

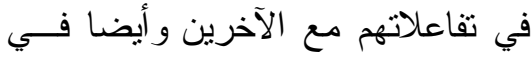

تحسن العمليــات المعرفيــة و المهنيــة

لاديهم.

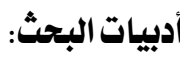

المحور الأول: الإعاقة العقلية:

مفهوم الإعاقة العقلية:

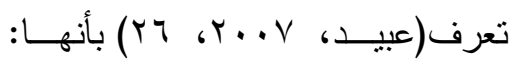

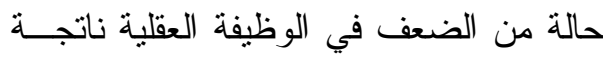

عن سوء التغذية أومرض ناشئ عن الإصابة

في مركز الجهاز العصبي.

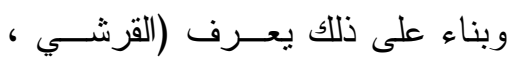

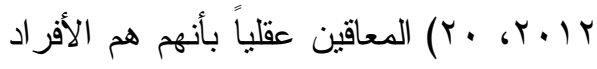

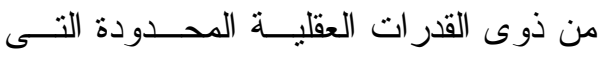

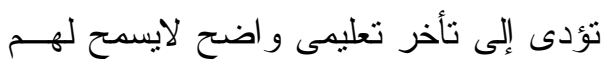

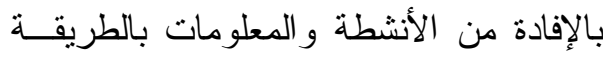

للتعلم على اكتساب المفاهيم و السلوكيات

والإتجاهات الوقائية اللازمة لإكــسابهم

الوعي الوقائي وذللك في ضو ء مجمو عة الإنها

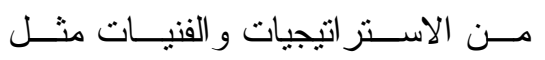

النمذجة و التعزيز ، بحيث تـسهرم هـــه النه

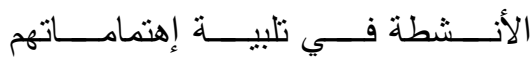

وإحتياجاتهم بأقل قدر ممكن من التدخل

$$
\text { الخارجي الموجه. }
$$

r. الوعى الوقائى : يُعرف الوعي الوقائي

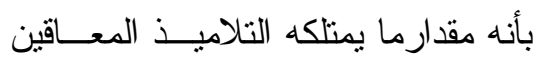
عقلياً من معسـارف ومـشـاعرو اتجاهات

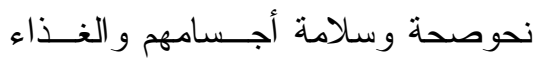
الصحي الذى ينعكس على سلوكهم في مواجهة المشكلات الصحية و الغذائيــة و الأمنية التى يتعرض لها في مدرسته،

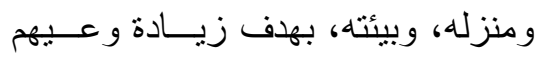

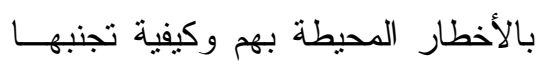
و الوقاية منها، وذللك من خلال مــنهج العلوم و الصحة بالمرحلة الإبتدائية فــي هني

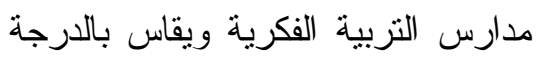

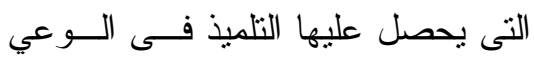
الوقائي المُعد فى البحث الحالي r. الإعاقة العقلية : تُعرف الإعاقة العقلية

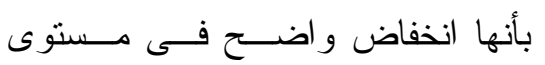

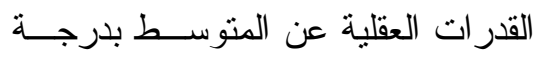
جوهرية، يتلازم معه عجز و اضح فى 
- فئة القابلين للتدريب Trainable -

تتز اوح نسبة ذكاء هذه الفئة ما بـين

هץ-00 درجة،وهذة الفئة غير قادرة على لـى

تعلم المهار ات الأساسية منل القر اءة و الكتابة

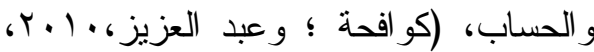

-

تتضمن هذه الفئة الأطفال الذين تقــلـ

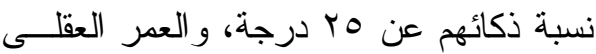
للفرد لا يزيد عن ثنلاث ســنوات، وهـــؤلاء

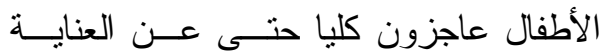

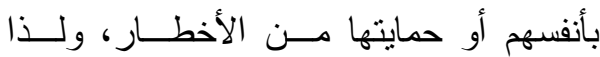
يعتمدون على غير هم طو ال حياتهم (كامــل

. (qr r... r. المحور الثاني:الوعي الوقائي مفهوم الوعي الوقائي:

يمكن تعريف الوعي الوقائي إجرائياً

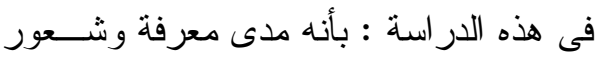
و إدر الك و اتجاهات التلاميذ المعاقين القـابلين للتعلم نحو صحة وسلامة أجسامهم و الغــذاء

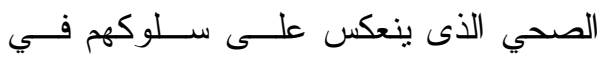

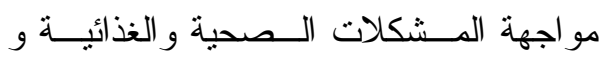

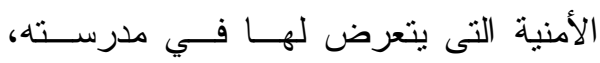

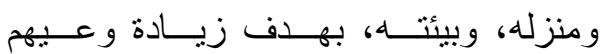

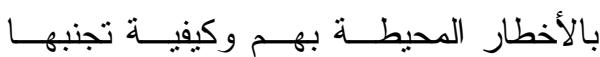
و الوقاية منها، وذللك من خلال منهج العلــوم

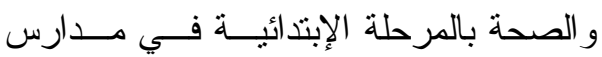

العادية، ويحتاجون إلـــى أســـاليب تعليميــة خاصة بالمقارنة بالتعليم العام؛ حتى يكتسبوا

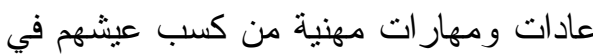
حدود قدر اتهم و استعدادتهم. تصنيف الإعاقة العقلية: اعتمدت الباحثة التصنيف التربوي للإعاقة العقلية وذلك كما يلي:

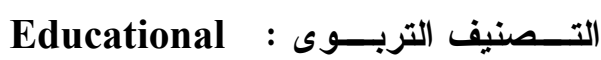

Classification

يقسم التربويون العاملون في مجــال الصحة النفسية المعاقين عقليــاً إلـى ثـــلاث مستويات طبقا للموقف التزبــوى وقــدرتهم على التعلم وذلك على النحو التالى: - مبئى التعلم The Slow Learners -

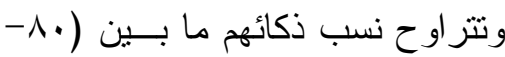
•9)، وهم قرييون جدا مسن الاعنتـاديين،

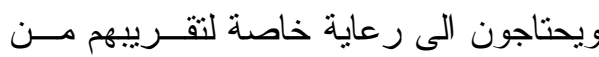

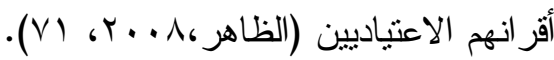
و هم من لديهم القدرة على الإســـفادة من البرامج التعليمية العادية ولكن بـصورة بطيئة ، فيحتاجون إلى برامج خاصة موجهة لإحداث تغير في السلوك الاجتماعي ليصبح

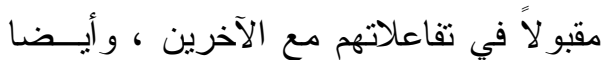
في تحسن العمليات المعرفية و المهنية لايهم ،

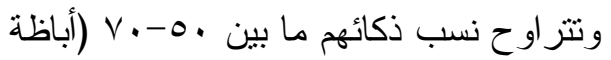
.(10، r... 


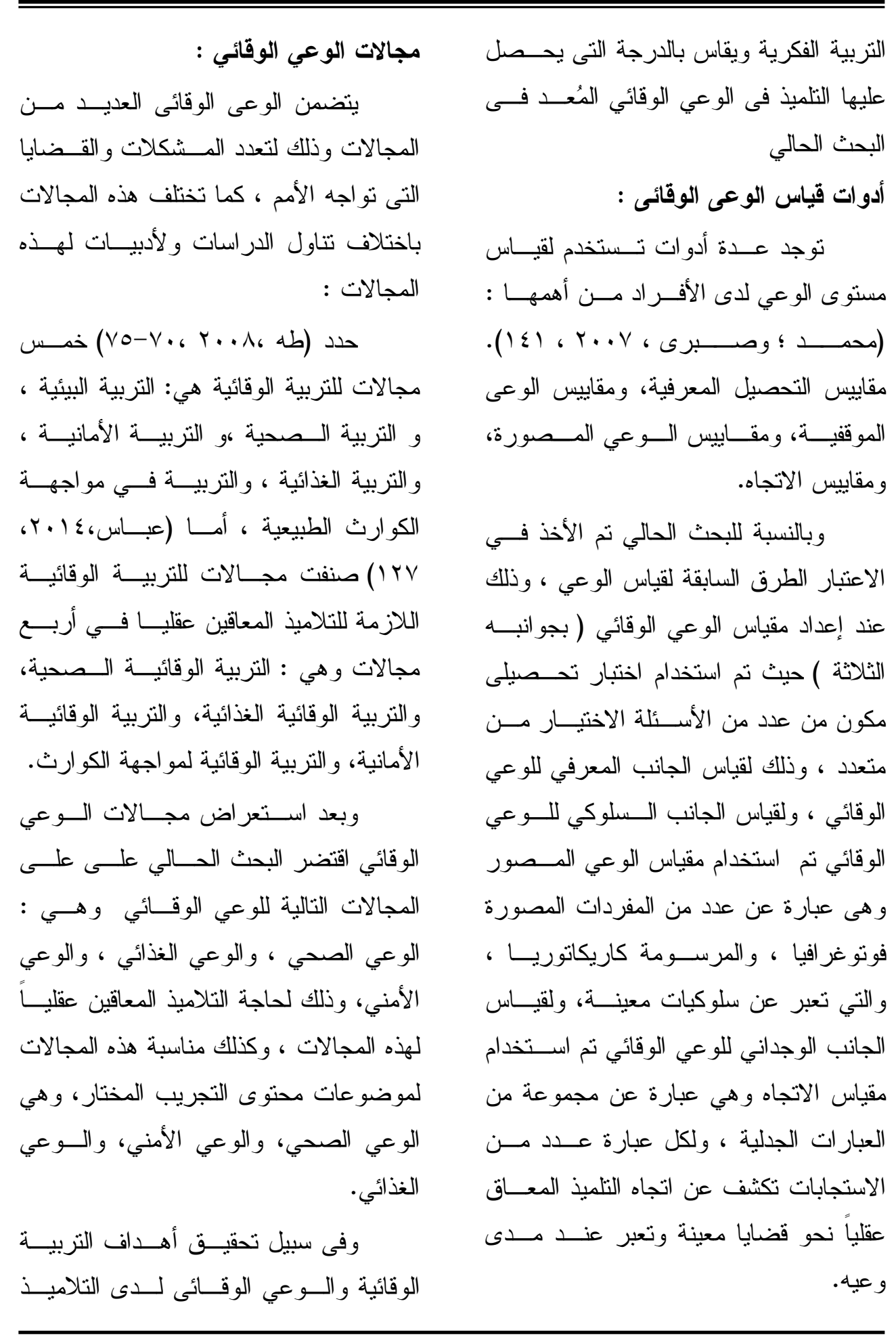


الوقائية للازمة لخفض القصور في الــوعي

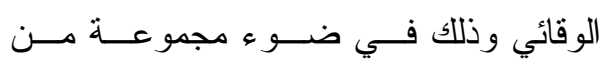

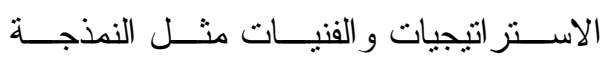
و التعزيز ، بحيث تسهم هذه الأنـشطة فـي لئي تلبية إهتماماتهم و إحتياجاتهم بأقل قدر ممكن من التذخل الخارجي الموجه . أنشطة منتسوري:

تنقسم أنشطة منتسوري إلى عـــدة أركــان

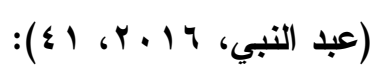

ا. ركن الحياة العملية: ويضم الأنـشطة التي تتمي لاى الطفل المهار ات الحياتية المختلفة منل انشطة الرعاية الثخصية،

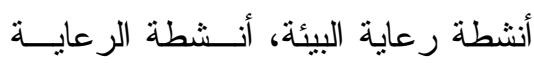
الاجتماعية، أنشطة حركية. r. ركن الحياة الحسية : ويشمل على كافة الأنشطة التي تتعامل مع حو اس الأطفال

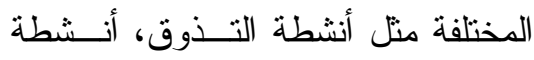

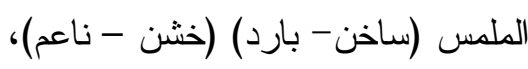
أنشطة الثم (الرو ائح المختلفة). r. ركن القراعة (اللغة): يهدف هذا الركن

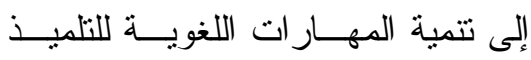

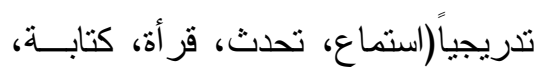

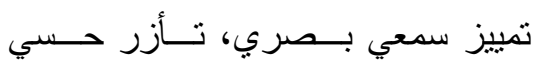
حركي) ويضم هذا الركن أنشطة الفهم

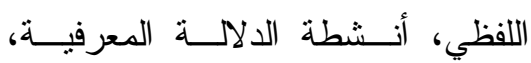
أنشطة اللغة المقرعوة، كذلك الأنـشطة

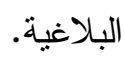

المعاقين عقلياً القابلين للتعلم ، فإن هناك عدد

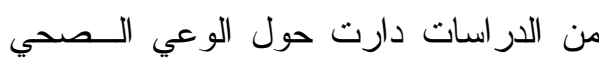

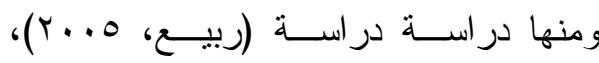

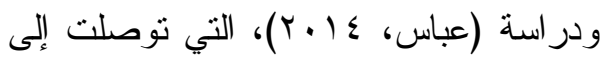

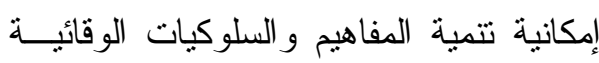

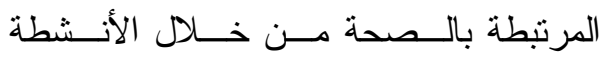

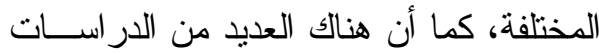

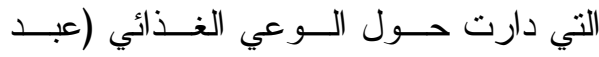

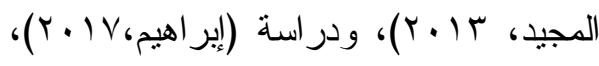

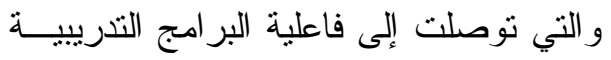
في تتمية الوعي الغـــائي، و هنـــاك أيــضـاً

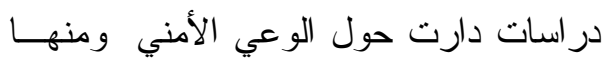

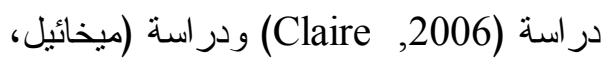

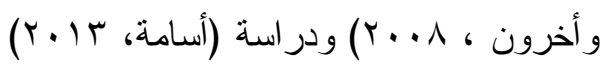

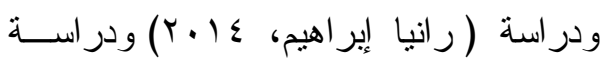

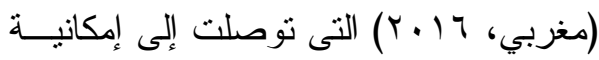
تدريب المعاقين عقلياً على سلوكيات التربية الأمانية باستخدام جداول الأنشطة المصورة. المحور الثالث: طريقـة ماريـا منتسوري في تعليه وتربية المعاقين عقلياً التعريف بطريقة منتسورى: يمكن تعريـف طريقـة منتـسوري إجرائياً : هي عبارة عن طريقة تعليمية تقوم على مجمو عة الأسس و المبادئ التي وضعتها

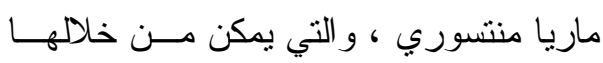

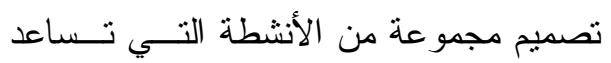

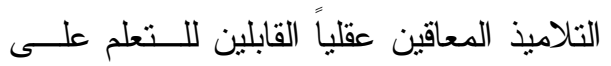
اكتساب المفاهيم و الــسلوكيات و الإتجاهـــات 
المحاكاة و التقليد، العوامل الأخلاقية، التعـبـ عند الأطفال، التخطيط و العمل مع الأطفــال،

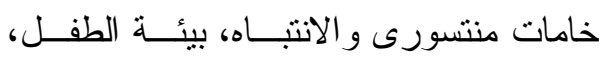
احتباجات المعلمة لتكون معلمة منتسورى.

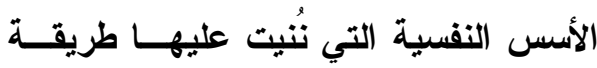
منتسوري في تربية التلميذ ذوي الإحتياجات

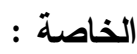

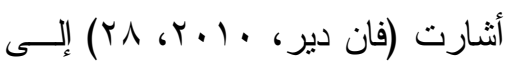

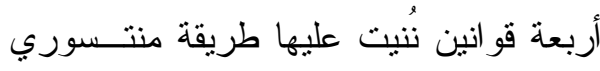
في تربية التلميذ ذوي الإحتياجات الخاصــة فئس وهي : 1. القانون الأول: و الذي يتمنل في الطريقة

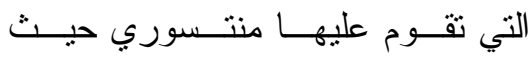
مخاطبة عقلية هؤلاء الأطفال من خلال علئ

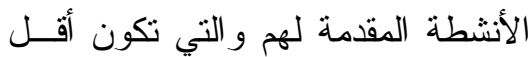
من الأنشطة التي يقوم بهـــا الأطفــال

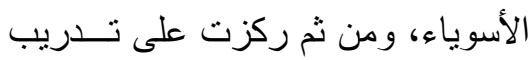

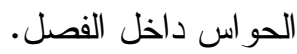
r. القانون الثاتي:مر اعاة التطور العقلــي

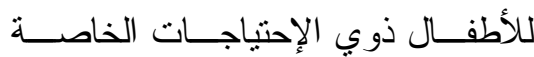
ومر اعاة ميولهم ، لذلك يجب أن تهــتم التربية بالمثير ات الغنية التي تؤدي إلى إهى

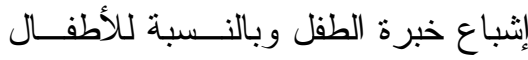

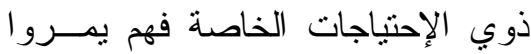
بلحظات نفسية يكون استعدادهم العقلي

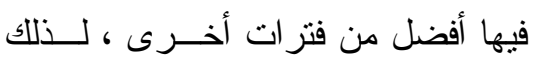
يجب إستثمار هذه الفتر ات .
ع. ركن القن: وهي تشمل على الأنــشطة

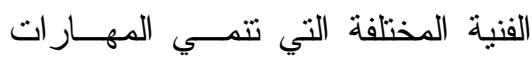

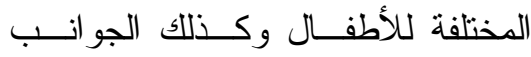
السلوكية منل أنشطة الرســم، أنسشطة

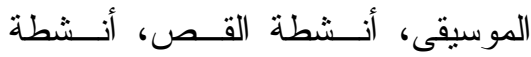

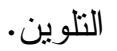
0. ركن الحساب : وهـو يـشتنمل علىى الأنشطة التي تهذف إلى تتمية المهارات

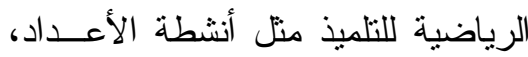
الأشكال الهندسية.

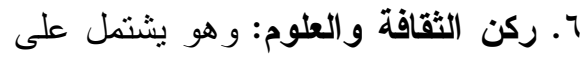
الأنشطة التي تهذف إلى تتمية المفــاهيم المختلفة عن العالم من حوله وتوســيع مداركه وزيادة معلوماته، فيتعرف على ملى ونى

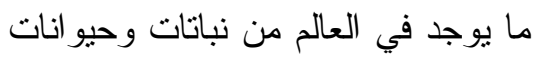

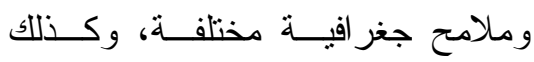
يتعرف على الظواهر العلمية المختلفة، ونه ومن أمنلة الأنشطة في هذا الركن نشاط

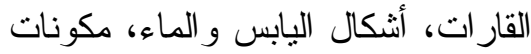

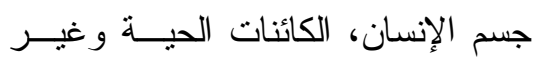
الحية، أجز اء الثجرة الإنسان مبادئ طريقة منتسوري :

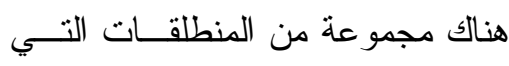

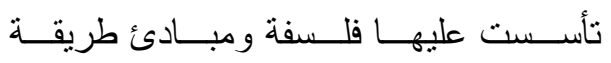
منتسوري وفيما يلي عرضاً لتلك المنطلة تـات وهي: المنهج المـستتبط مــن الملاحظـــة، 


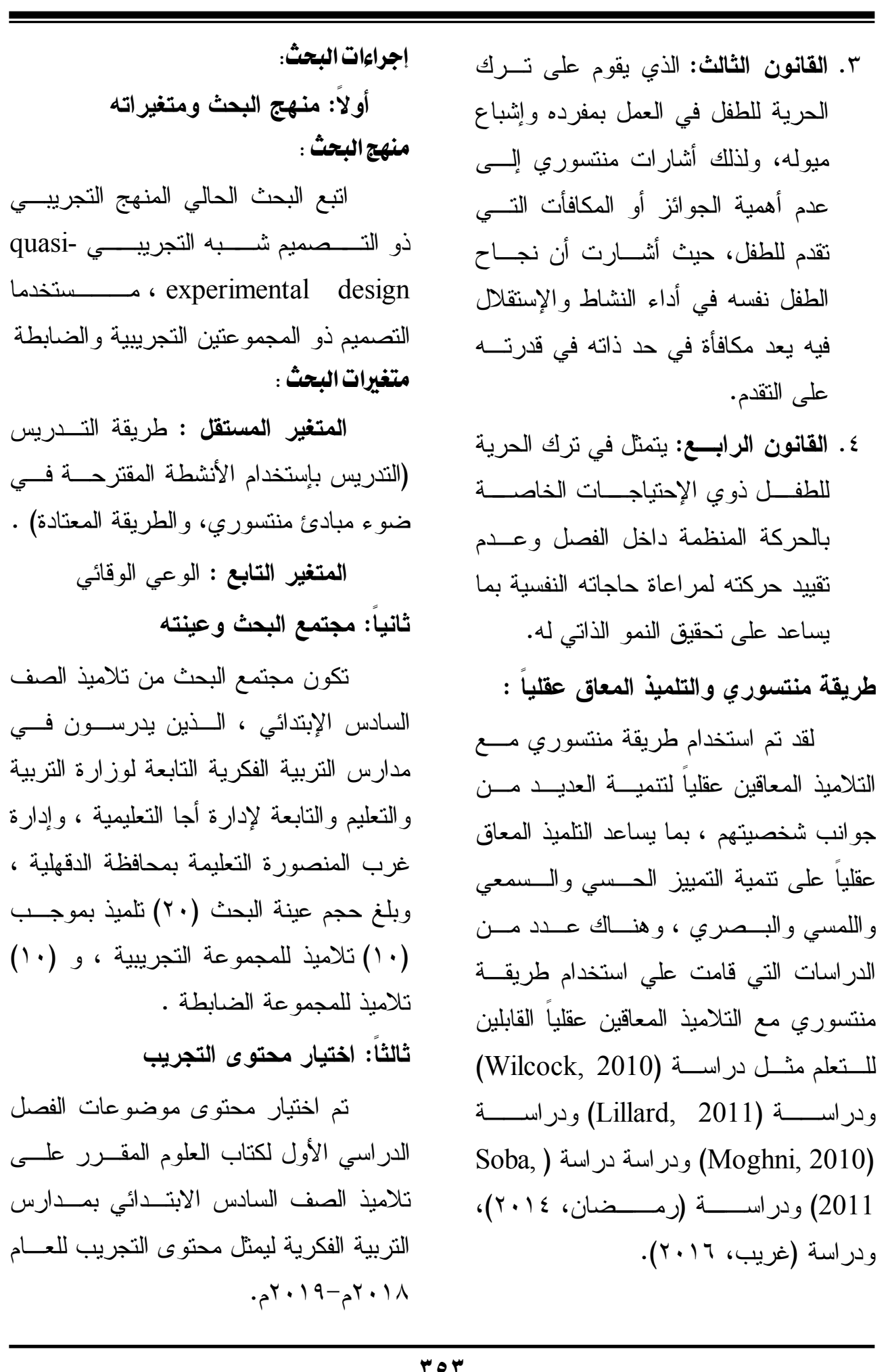


- الخطـــة الزمنيــة المقترحسـة لتــدريس

موضو عات الدليل.

- تم توزيع محتوي الفصل الدراسي على موصن

عدد من الحصص المقررة وتـضنتن

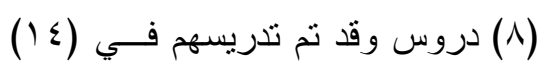

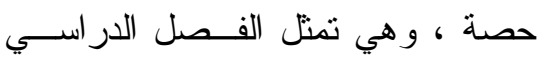

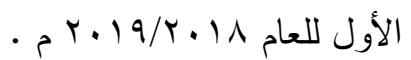

- - صياغة الدروس بالدليل.

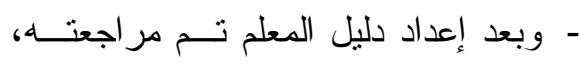

وبذللك أصبح الدليل في صورته الأولية

جاهزاً للعرض على المحكمين. -

تم عرض دليل المعلم على مجموعــة

من المحكمـين المتخصــصين فـي مجــال

المناهج وطرق تــدريس العلــوم و الفئـات

الخاصة ، وبلغ عددهم (9) لإِبداء آر ائهـ

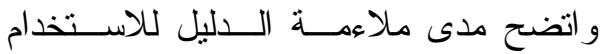

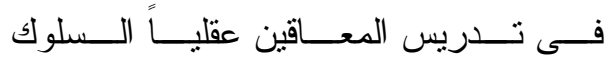

الوقائي.

r. إعداد دليل أنثطة التلميذ

تم إعداد دليل أنشطة التلميــذ بحيــــ

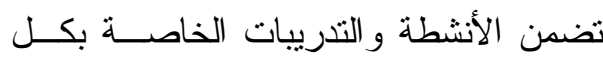

درس ، وقد تم صياغة الأنشطة بحيث تكون

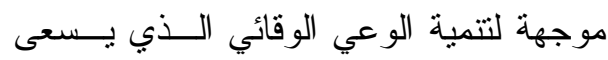

البحث الحالي إلى تتميته، ويعتمد دليل أنثطة

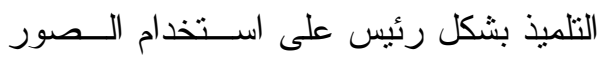

المرتبطة بالنشاط.
رابعاً: إعداد مواد المعالجة التجريبية

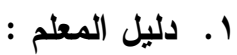

تم إعداد الدليل على النحو الآتي:

- مقدمة الدليل

- تم صياغة مقدمة الدليل موجهة إلى معلم

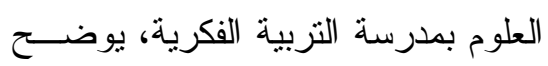

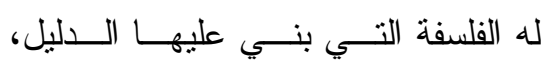

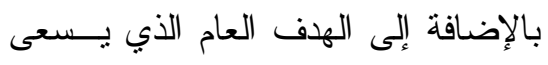

لتحقيقه.

- ت تعليمات عامة للمعلم.

- للإسنترشاد بها عند تتفيذ أنسشطة دروس لمعان

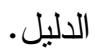

- الأهداف العامة لتـدريس موضـــوعات

الفصل الدر اسي الأول

- تم صباغة الجوانــب الثلاثــة للــوعي التولي

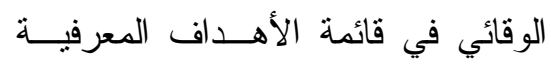

و المهارية و الوجدانية لموضو عات وهي: الوهي:

الإنسان ، أجزاء جسم الإنسان ، ووجها لونه

الإنسان ، وخصائص الإنسان ، و الغذاء ، إلغنان ، ووجهاء

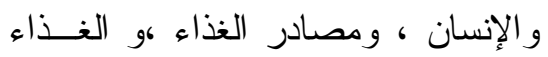

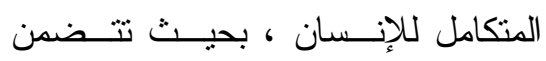

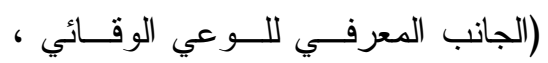

و السلوكيات الوقائية ، و القيم و الاتجاهات

الوقائية ) لدى التلاميذ المعاقين عقليـاً

بمدرسة التربية الفكريــة مــن خــلادل

در استهم لموضوعات الفصل الدر اســي لئي

الأول باستخدام دليل المعلم • 
تم الاقتصـار في تحديــــ المـستويات

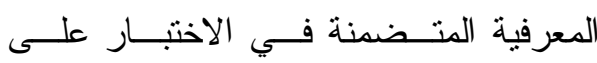

المستويات المعرفية الثلاتــة الأولــي مــن

المستويات السته التي حددها بلــــوم للمجــــال

المعرفي وذلك باعتباره أكثتـر التــنيفات

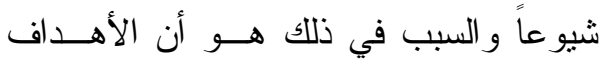

المعرفية لمحتوى التجريب كانت تدور فـي

معظمها حول نلاك المستويات الثناثةة، ورهــذه

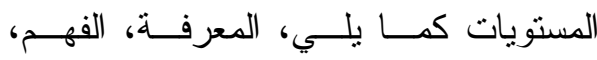

$$
\text { و التطبيق. }
$$

ج- إعداد جدول المواصفات:

تم تقسيم محتوى الفـصل الار اســي

الأول إلي مجموعــة مــن الموضـــوعات،

وتحديد عدد الأسئلة الخاصة بكل موضــوع

وفقاً لأبعاد الوعي الوقائي الثالثة ( الصحي،

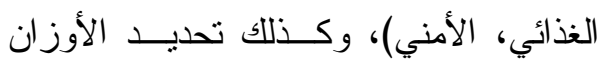

النسبية للمستويات المعرفية الثلاثة ( التنكر،

و الفهم، و التطبيق) من خلال تطبيق المعادلة الآتية:

الوزن النسبي للمستويات المعرفية =

عدد الأسئلة فـي المـستوى / مجموعـة

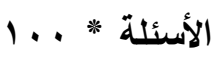

وبعد الإنتهاء من إعداد دليل أنـشطة

التلميذ فى صورته الأولية، تم عرضنه علـى ملى

مجموعة من المحكمين المتخصــصين فــي

مجال المناهج وطرق تدريس العلوم و الفئات

الخاصة ، وبلغ عددهم (9) لإبداء آرائهــ

و اتضتح ملاعمة مستوى الأتـشطة بالنــسبة

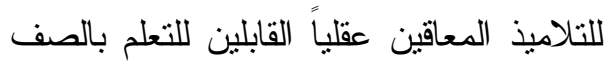

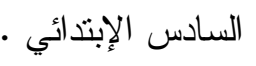
r. إعداد مقياس الوعي الوقائي

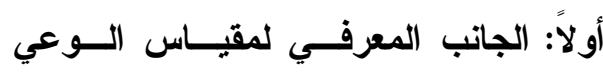
الوقائي :

أ- تحديا الهرف مــن الجانـب المعرفـي

$$
\text { لمقياس الوعي الوقائي : }
$$

استهدف الجانب المعرفــي للمقيــاس

المستخدم في الدر اسة الحالية تحديـــــ مقــدار

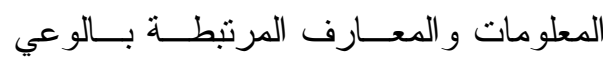

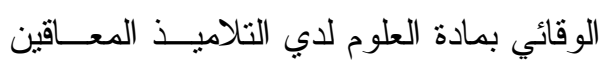
عقلياً المرتبطة بموضوعات الفصل الدراسي الأول. - الت.

ب-تحديد المستويات المعرفية المتـضمنة في اختبار الجانب المعرفـي للــوعي الوقائي: 


\begin{tabular}{|c|c|c|c|c|c|}
\hline الأهمية النسبية & المجموع & التطبيق & الفهم & 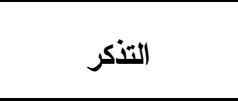 & المستويات \\
\hline$\% \leqslant r$ & 9 & $1 \cdot-\varepsilon-1$ & $r \cdot-1 \leqslant-1 r$ & r)-9-7 & الصحي \\
\hline$\% \leqslant r$ & 9 & $19-\Lambda$ & $1 V-r$ & $1 \wedge-17-10-V-r$ & الغذائي \\
\hline \multirow[t]{2}{*}{$\% 1 \leq$} & $r$ & - & $|r-1|-0$ & - & الأمني \\
\hline & & 0 & $\Lambda$ & $\Lambda$ & \\
\hline$\% 1 \ldots$ & r) & $\%$ \% & $\%$ \% & $\%$ \% & اللأهمية النسبية \\
\hline
\end{tabular}

مجموعة البحث الأساسية_ بمدرسة التربيــة

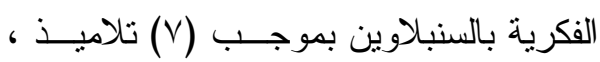

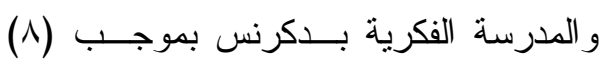

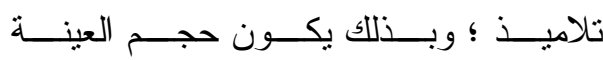

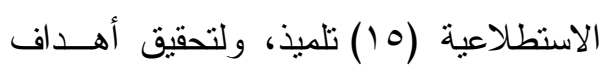

$$
\text { التجربة الاستطلاعية تم الآتي: }
$$

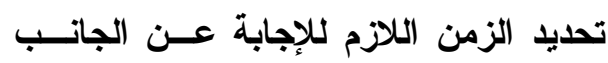

$$
\text { المعرفي لمقياس الوعي الوقائي : }
$$

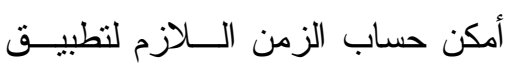

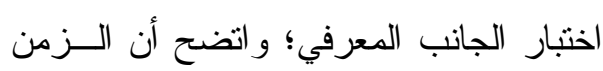

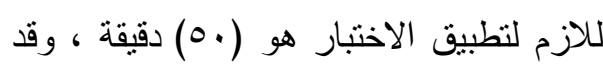
تم الالتز ام بهذا الزمن عند التطبيقين (القبلــي

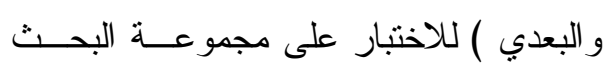
الأساسية .

\section{حساب معامل ثبات الاختبار :}

نم حساب معامل الثبــات باســتخدام معادلة ألفا كرونباخ و اتضح أن معامل ثبات

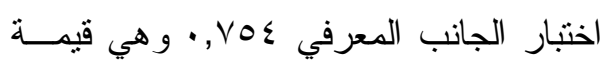

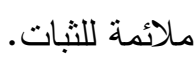

د - صــياغة مفــردات الجانسـب المعرفــي لمقياس الوعي الوقائي :الضبط العلمي

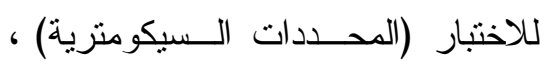

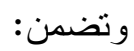

ه- تحديد صدق محتوى الاختبار : (صــدق (المحكمين )

تم عرض الصورة الأوليـــة لاختبـــار

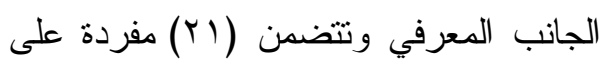
مجموعة من المحكمين في مجــال المنــاهج وطرق تدريس العلوم و الفئات الخاصة وبلغ فئ

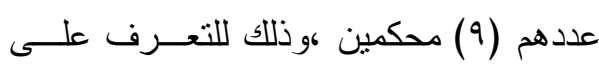
آر ائهم في الاختبار ، و أسفرت نتائج التحكيم

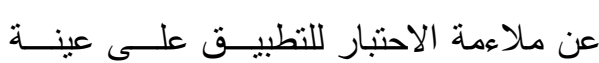
البحث الأساسية. التجربــة الإســنطلاعية لإختبــار الجانــب المعرفي للوعي الوقائي: تم تطبيق اختبار الجانب المعرفي في صورته المبئية على مجموعة على عينة من

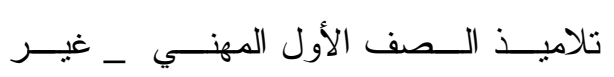




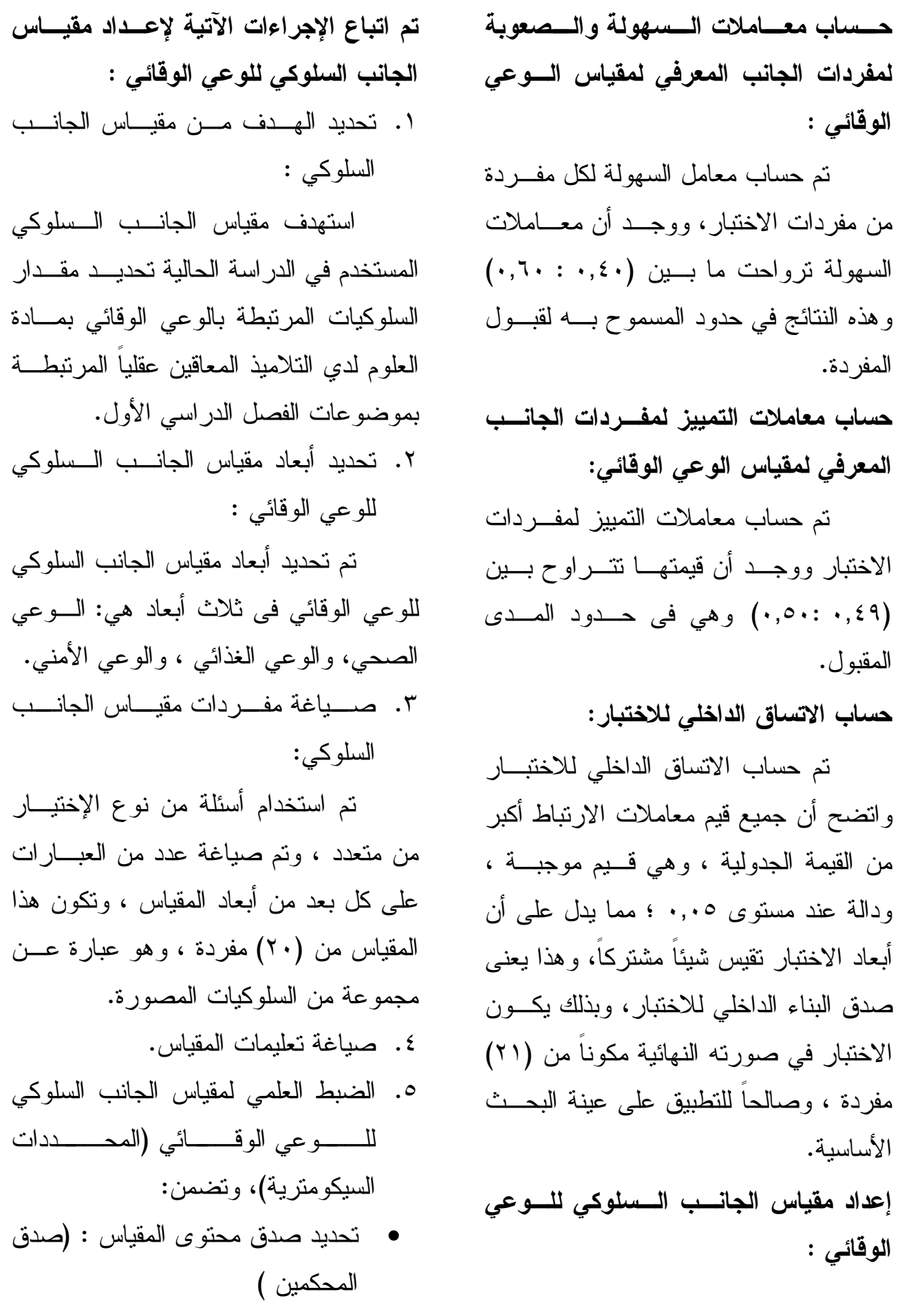


تم حساب الاتساق الداخلي للمقيــاس،

بحساب معامل الإرتباط بين درجات مفردات

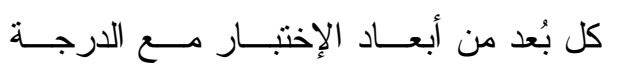

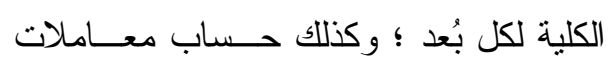

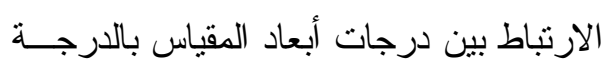

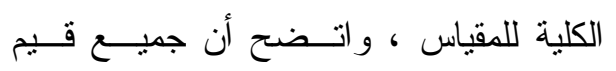

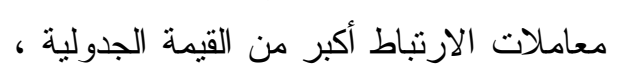
وهي قيم موجبة ، ودالة عند مستوى 0 .,. ؛ مما يدل على أن أبعاد المقياس تقيس شيئًاً

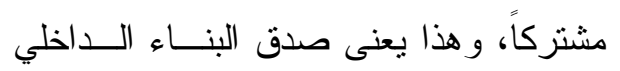
للمقياس

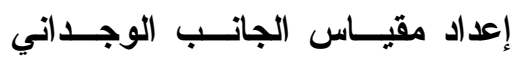
للوعي الوقائي :

تم اتباع الإجراءات الآتية لإعـــداد مقيــاس الجانب الوجداني للوعي الوقائي : ا. تحديد الهــدف مــن مقيــاس الجانـبـ الوجداني : أحيد

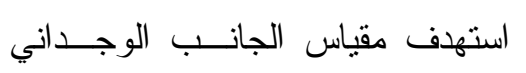

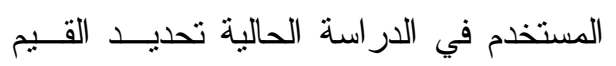
و الإتجاهات المرتبطة بالوعي الوقائي بمــادة

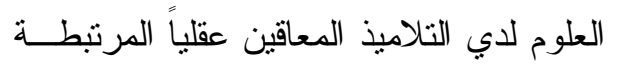
بموضوعات الفصل الدر اسي الأول. r. تحديد أبعاد مقياس الجانب الوجداني :

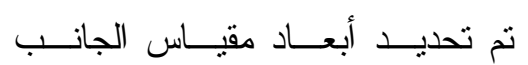
الوجداني للوعي الوقائي فى ثلاث أبعاد هي:
تم عرض الصورة الأوليـــة لمقيــاس

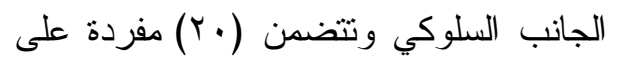
مجموعة من المحكمين في مجــال المنــاهج وطرق تدريس العلوم و الفئات الخاصة وبلغ من مدن

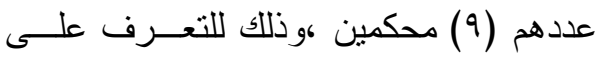
آر ائهم في المقياس.

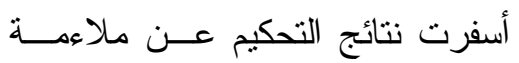

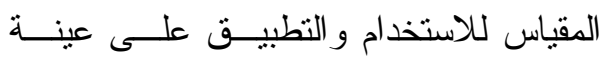
البحث الأساسية.

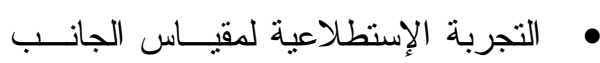
السلوكي للوعي الوقائي: تم إجــر اء التجربــة الإســنطلاعية

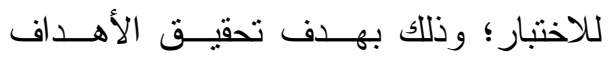
الآتية :

ا. تحديد الزمن الــلازم للإجابــة عـن الـن المقياس: - المباس أمكن حساب الزمن الــلازم لتطبيــق

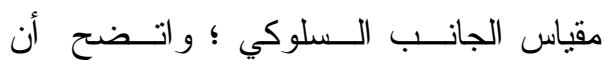

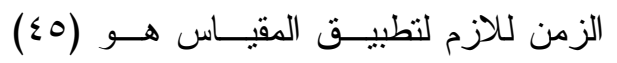
دقيقة. r. حساب معامل ثبات مقيــاس الجانــب السلوكي : تم حساب معامل الثبــات باســتخدام معادلة ألفا كرونباخ و اتضح أن قيمة الثبــات

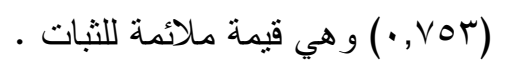

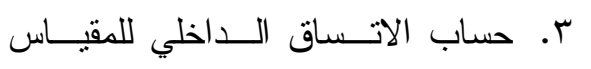

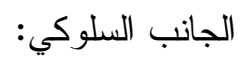


و أسفرت نتائج التحكيم عن ملاءمـــة

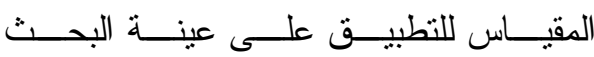

$$
\text { الأساسية. }
$$

التجربة الإستطلاعية لمقياس الجانـب

$$
\text { الوجداني للوعي الوقائي: }
$$

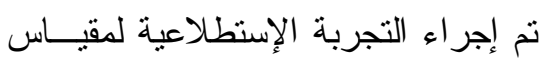

الجانب الوجداني للوعي الوقائي ؛ وذلك اءلك

بهدف تحقيق الأهداف الآتية :

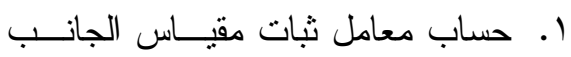

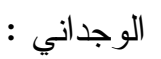

نم حساب معامل الثبــات باســتخدام

معادلة ألفا كرونباخ و اتضـح أن قيمة التبــات

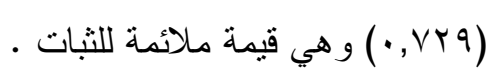

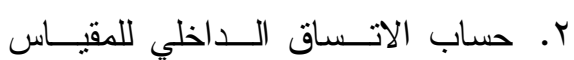

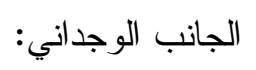

تم حساب الاتساق الداخلي للمقيــاس،

بحساب معامل الإرتباط بين درجات مفردات

كل بُعد من أبعاد المقياس مع الدرجة الكليـــة

لكل بُعد ؛ وكذلك حساب معاملات الارتباط

بين درجات أبعاد المقياس بالدرجـــة الكليـــة

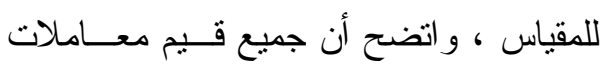
الارتباط أكبر من القيمة الجدولية ، وهي قيم

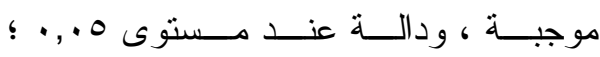
مما يدل على أن أبعاد المقياس تقيس شـــئاً

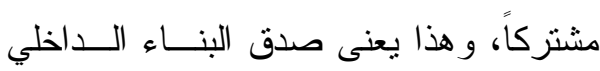

$$
\begin{aligned}
& \text { الوعي الصحي ، و الوعي الغذائي ، و الوعي }
\end{aligned}
$$

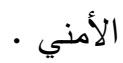

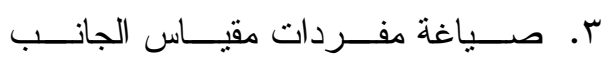

$$
\begin{aligned}
& \text { الوجداني : }
\end{aligned}
$$

تم صياغة عدد من العبارات على كل

بعد من أبعاد المقياس ، وتكون هذا المقياس

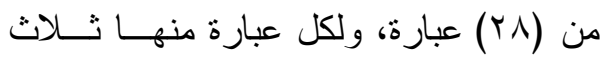
استجابات وهى (موافق، غير متأكد، غيــــر

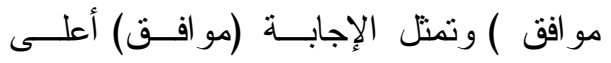

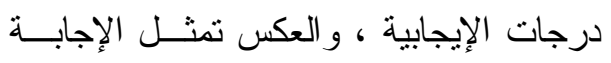

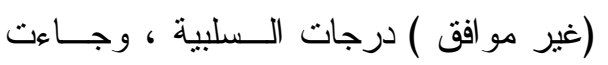

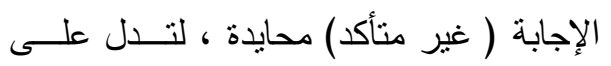
التردد في وجود الإتجاه ، وكذللك تم صياغة

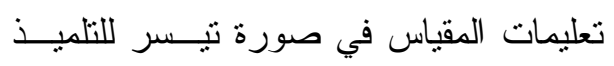

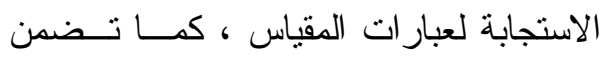
المقياس نوعين من العبار ات موجبة وسالبة . ع. ـ صياغة تعليمات المقياس. ه. الضبط العلمي لمقياس الجانب الوجداني تعلي (المحددات السيكومترية) ، وتضمن:

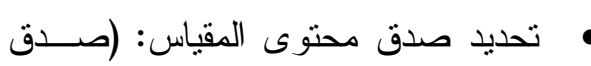
المحكمين ) تم عرض الصورة الأوليــة لمقيــاس

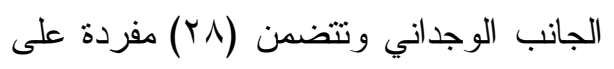
مجموعة من المحكمين في مجــال المنــاهج وطرق تدريس العلوم و الفئات الخاصة وبلغ

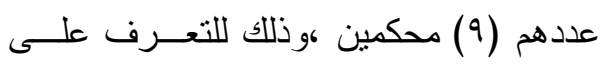
آر ائهم في المقياس. 
و الجانب الوجداني ) نم استخدام معادلة مان وتتي لتحديد دلالة الفرق بين منوسطى رنب

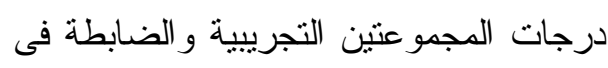

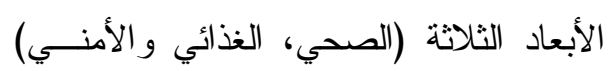

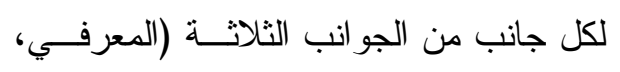

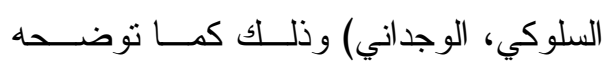

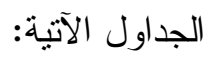

سادساً: إجراءات تجربة البحث التطبيق القبلي لأدوات البحث : تم تطبيق أدوات البحث قبلياً في يومي لادوات 乏 المجمو عنين ( التجريبية ، و الضابطة ) فـي وني

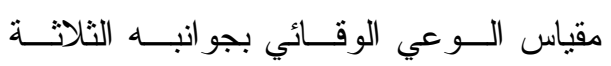

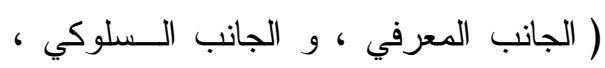

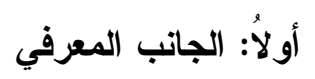

جدول (10)

قيمة " U " ودلالتها الإحصائية للفروق بين رتب درجات المجموعتين التجريبية و الضابطة

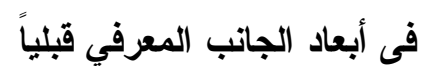

\begin{tabular}{|c|c|c|c|c|c|c|c|}
\hline الإحصائية & مستوى الدلالة & قيمة " “ ق U & مجموع الرتب & متوسط الرتب & ن & المجموعة & الأبعاد \\
\hline \multirow[t]{2}{*}{ غير دالة } & $\cdot$, A & $\varepsilon \wedge$ & $1 \cdot r$ & $1 \cdot, r$. & $1 \cdot$ & ض & صحي \\
\hline & & & $1 \cdot V$ & $1 \cdot, \mathrm{r}$. & 1. & ت & \\
\hline \multirow[t]{2}{*}{ غير دالة } & $\cdot, \leqslant 9$. & $\varepsilon r$ & 9V & $9, \vee$. & 1. & ض & غذائي \\
\hline & & & $11 \pi$ & $11, r$. & 1. & $ت$ & \\
\hline \multirow[t]{2}{*}{ غير دالة } & $\cdot, 170$ & $\varepsilon \wedge$ & $1 \cdot V$ & $1 \cdot, v$. & $1 \cdot$ & ض & أمنى \\
\hline & & & $1 . r$ & $1 \cdot, r$. & 1. & $ت$ & \\
\hline \multirow[t]{2}{*}{ غير دالة } & $\cdot, \vee \vee r q$ & $\leqslant 0,0$ & $1 \cdots, 0$. & $1 \cdot, .0$ & 1. & ض ض & درجة كلية \\
\hline & & & $1.9,0$. & $1 ., 90$ & 1. & $ت$ & \\
\hline
\end{tabular}

التجريبية و الــضـابطة فـى أبعـاد الجانـب

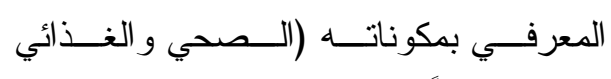

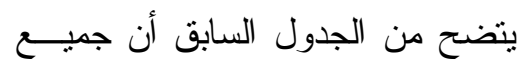
يدل على وجود تكافؤ بين مجموعتي البحث والأمني) قبلياً. 


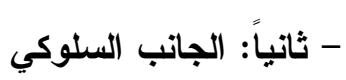

جدول (1 ) (19)

قيمة " U " ودلالتها الإحصائية للفروق بين رتب درجات المجموعتين التجريبية و الضابطة فى أبعاد الجانب السلوكي قبلياً

\begin{tabular}{|c|c|c|c|c|c|c|c|}
\hline الإحصائية & مستوى & قيمة " “" U & مجموع الرتب & متوسط الرتب & ن & المجموعة & الأبعاد \\
\hline \multirow[t]{2}{*}{ غير دالة } & $\cdot, \vee \wedge \wedge$ & $\leq 7,0$ & $1,1,0$. & $1, .10$ & 1. & ض & صحي \\
\hline & & & $1 . \wedge, 0$. & 10,10 & 1. & ت & \\
\hline \multirow[t]{2}{*}{ غير دالة } & $\cdot, \wedge \vee \uparrow$ & $\varepsilon \Lambda$ & $1 . r$ & $1 \cdot, r$. & 1. & ض & غذائي \\
\hline & & & $1 . V$ & $1 \cdot, \mathrm{r} \cdot$ & 1. & ت & \\
\hline \multirow[t]{2}{*}{ غير دالة } & . VYO & $\leq 0,0$ & $1 \ldots, 0$. & $1 ., .0$ & 1. & ض & أمنى \\
\hline & & & $1.9,0$. & $1 ., 90$ & 1. & $ت$ & \\
\hline \multirow[t]{2}{*}{ غير دالة } & $\cdot, \lambda \vee \vee$ & $\leqslant \wedge$ & $1 . r$ & $1 \cdot, r$. & 1. & ض & درجة كلية \\
\hline & & & $1 . V$ & $1 \cdot, v$. & 1. & 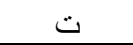 & \\
\hline \multicolumn{8}{|c|}{ البحث التجريبية و الضابطة فى أبعاد الجانب } \\
\hline \multicolumn{8}{|l|}{ 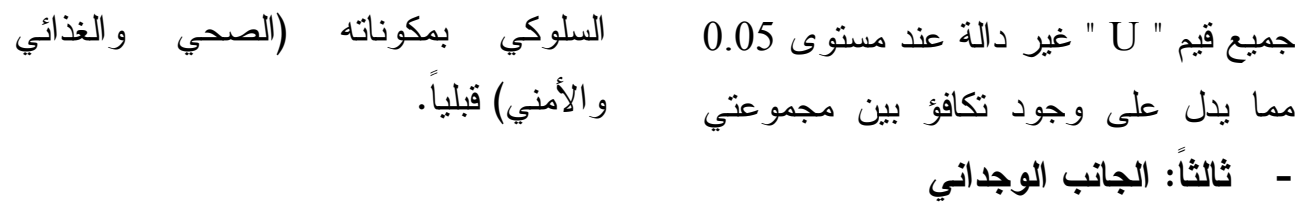 } \\
\hline
\end{tabular}

جدول (iv)

قيمة " U " ودلالتها الإحصائية للفروق بين رتب درجات المجموعتين التجريبية والضابطة فى أبعاد الجاتب الوجداني قبلياً

\begin{tabular}{|c|c|c|c|c|c|c|c|}
\hline الإحصائية & مستوى الدلاكة & 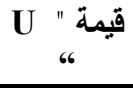 & مجموع الرتب & متوسط & ن & المجموعة & الأبعاد \\
\hline \multirow[t]{2}{*}{ غير دالة } & $\cdot, r \wedge 9$ & rq & $9 \leq$ & १,६. & 1. & ض & صحي \\
\hline & & & 117 & $11,7$. & 1. & ت & \\
\hline \multirow[t]{2}{*}{ غير دالة } & •, AlV & $\varepsilon V$ & $1 . r$ & $1 \cdot, r$. & 1. & ض & غذائي \\
\hline & & & 1.1 & $1 \cdot, \wedge$. & 1. & $ت$ & \\
\hline \multirow[t]{2}{*}{ غير دالة } &., oro & $\varepsilon r$ & $9 v$ & $9, v \cdot$ & 1. & ض ض & أمنى \\
\hline & & & $11 \%$ & $11, r$. & 1. & ت & \\
\hline \multirow[t]{2}{*}{ غير دالة } &.,$r \vee$. & $r 0,0$ & $9 \cdot, 0$. & $9, .0$ & 1. & ض & درجة كلية \\
\hline & & & $119,0$. & 11,90 & 1. & ت & \\
\hline
\end{tabular}


التدريس ، وقد تم التصحيح و إجر اء المعالجة

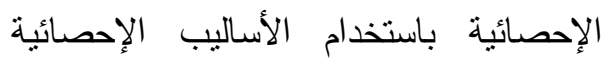
الملائمة في ضوء حجم العينة وطبيعة

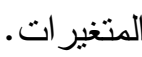
نتائج البحث (مناقشتها_تفسيرها) أولاً: النتائج المتعلقة بالسؤال الأول: للإجابة عن السؤال الأول من أسئلة البحث ، تم اختبار الفرض الأول من فروض الاون من

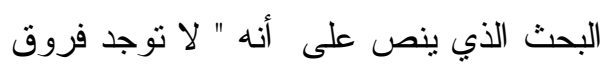

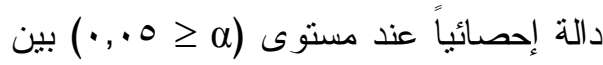
متوسطى رتب درجات طلاب المجموعة التجريبية و المجموعة الضابطة في الجانب دئب المعرفي لمقياس الوعي الوقائي بعدياً"

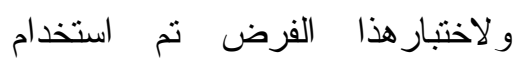

معادلة (مان وتتي) لتحديد دلالة الفرق بين

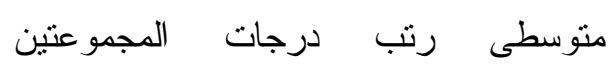
التجريبية و الضابطة في الأبعاد الثلاثة

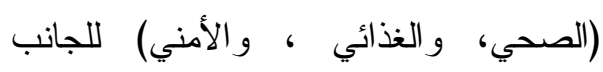

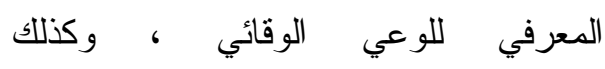
الدرجة الكلية، والجدول (^) الآتي يوضح * ذلك.

* نم تصحيح مستوى الدلالة 0. ., . إلى 0 1 | . , • وفقاً لتصحيح بنفروني.
يتضح من الجدول (lv) السابق أن

جميع قيم " U " غير دالة عند مسنوى 0.05 مما بدل على وجود تكافؤ بين مجموعني

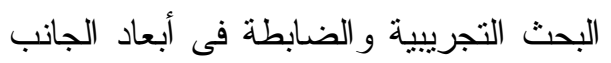

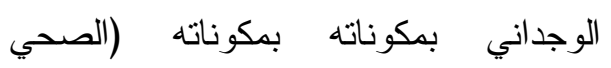
و الغذائي و الأمني) قبلياً. ثانياً : إجراءات أثناء التطبيق الميداني : تمثلت تلك الإجراءات في : التدريس للمجموعتين التجريبية والضابطة بدأ النطبيق الفعلي للبحث للمجموعة

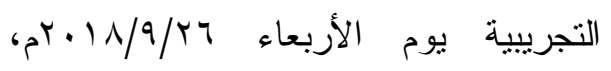
و المجموعة الضابطة يوم ل الخميس 1 11/9/Tr أسبوعياً لكل منهما حيث استغرق التدريس

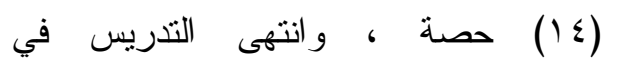

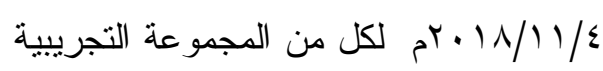
و المجموعة الضابطة حيث قامت الباحثة

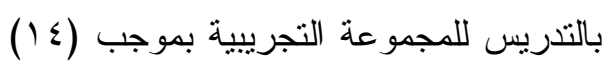
حصة ، و إسناد التدريس المجموعة الضابطة لمعلم العلوم بمدرسة التربية الفكرية بالمنصورة. ثالثاً : إجراعات بعد التطبيق الميداني : بعد الإنتهاء من تدريس الموضوعات تم تطبيق أدوات البحث بعدياً وذلك يومي لإنهاء

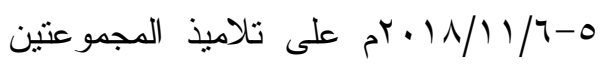
التجريية و الضابطة على نحو ما نم قبل 


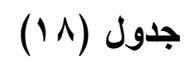

قيمة " U " ودلالتها الإحصائية للفروق بين رتب درجات المجموعتين التجريبية والضابطة فى أبعاد الجانب المعرفي والدرجة الكلية بعدياً.

\begin{tabular}{|c|c|c|c|c|c|c|c|}
\hline الإحصائية & مستوى & قيمة " ق ق " & مجموع الرتب & متوسط & ن & المجموعة & الأبعاد \\
\hline \multirow[t]{2}{*}{ دالة } &.,$\ldots$ & 15,0 & $7 \wedge, 0$. & 7,10 & 1. & ض | ل م & صحي \\
\hline & & & $1 \leqslant 1,0$. & $1 \leqslant, 10$ & 1. & ت & \\
\hline \multirow[t]{2}{*}{ دالة } & .,... & 10 & $v_{0}, \cdot$. & $v, .$. & 1. & 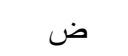 & غذائي \\
\hline & & & $1 \leqslant \cdot, \cdot$. & $1 \varepsilon, \cdot$. & 1. & ت & \\
\hline \multirow[t]{2}{*}{ غير دالة } & .,OYY & $\varepsilon r, 0$ & $q \vee, O$. & $9, v_{0}$ & 1. & 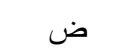 & أمنى \\
\hline & & & $11 r, 0$. & $11, r_{0}$ & 1. & ت & \\
\hline \multirow[t]{2}{*}{ دالة } &.,. .1 &., 0 & 00,0 . & 0,00 & 1. & 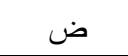 & درجة كلية \\
\hline & & & $10 \leqslant, 0$. & 10,50 & 1. & ت & \\
\hline
\end{tabular}

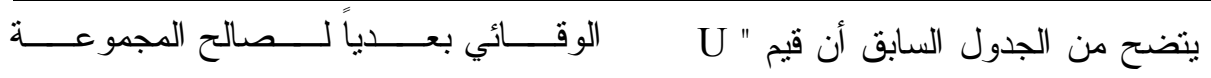

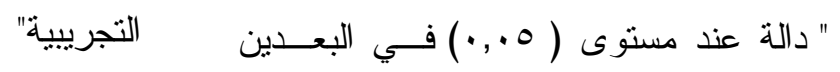

حجم التأثير لاستخدام أنثطة قائمسـة

على مبادئ منتسوري

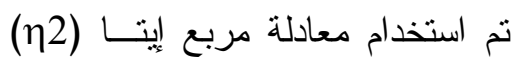

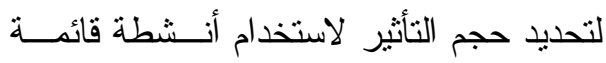

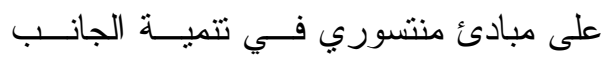
المعرفي للوعي الوقائي لاى التلاميذ المعاقين

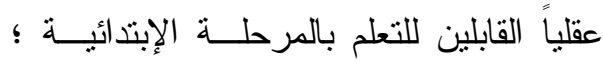

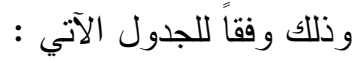

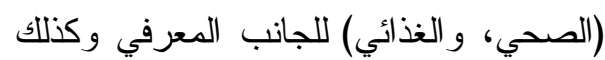

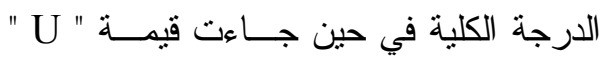
غير دالة فى البعد الأمني بعدباً.

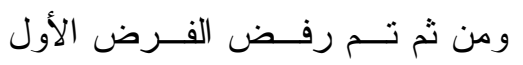

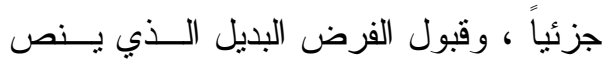

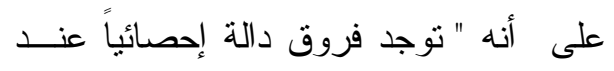

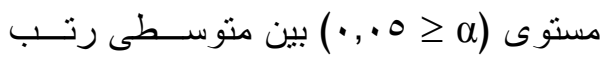

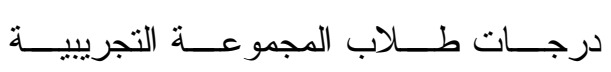

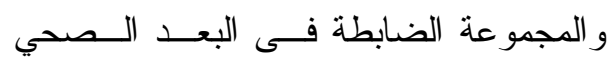

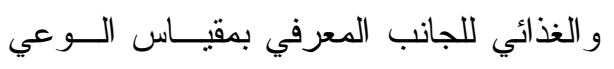




\section{جدول (r)}

حجم تأثثير أنشطة منتسوري فى تنمية الجانب المعرفي

\begin{tabular}{|c|c|c|c|}
\hline حجم التأثير & $\eta 2$ & قيمة " Z " & الأبعاد \\
\hline كبير & זד, & $r, A Y A$ & صحي \\
\hline كبير & זד, . & $r, V Y T)$ & غذائي \\
\hline كبير & . , 10 & $r$ r,vAт & رجة كلية \\
\hline
\end{tabular}

مثير ات أخرى في البيئة المحيطة بهر ، وهذا

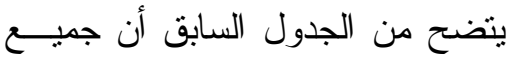

ساعدهم على تذكر المعلومات التي اكتسبوها لئه

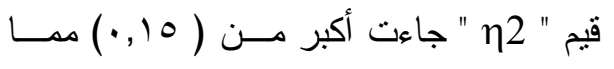

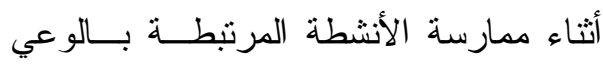

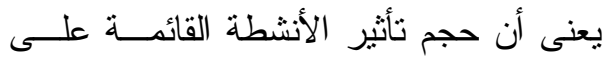

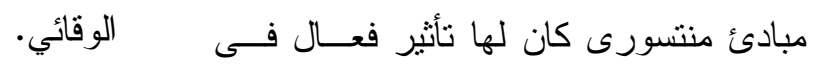

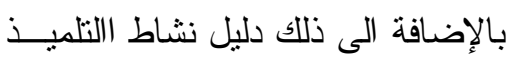

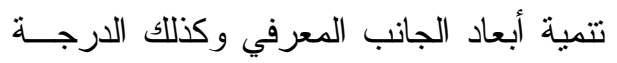
الذي تضمن العديد من الأنشطة المتتوعة قد دئل

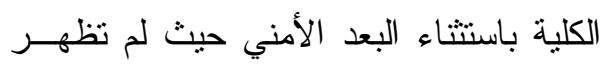
منل تتويعاً جيداً للمثيرات التي مــن شــــن أنها

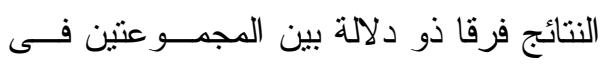
جذب انتباهم مما أدى إلــى رفـــع دافعيــنهم

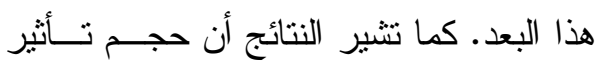

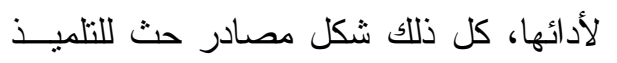
للإقبال على تتفيذ تلك الأنشطة ؛ مما أســـهم الأنشطة فى الدرجة الكلية للجانب المعرفـي لئي

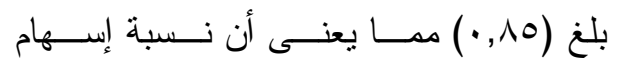

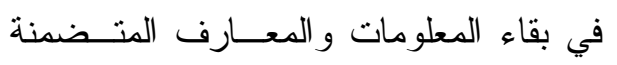

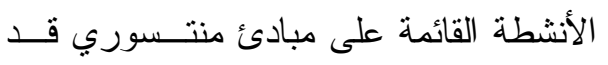
بالمحتوي الدر اسي موضع التجريب ونمو ها،

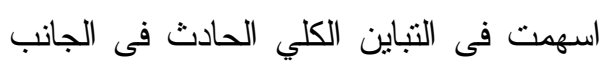

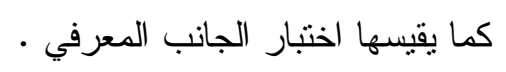
وتتفق نتائج البحث الحالي مع نتـائج

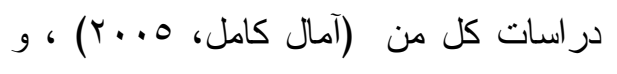

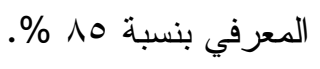

\section{مناقـــة النتـــائج التتعلقــــة بالـــــؤال الأول}

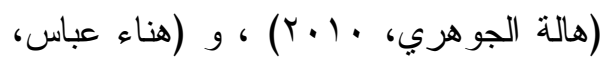
قد يرجع تحقيق تلاميــــ المجموعـــة

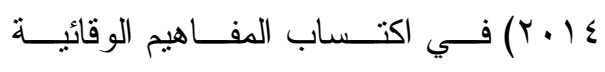

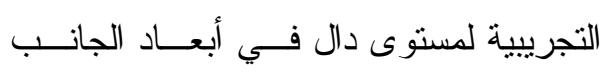

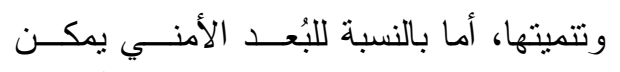

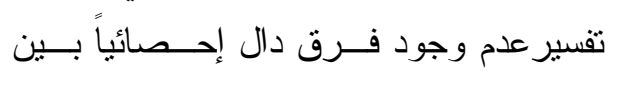

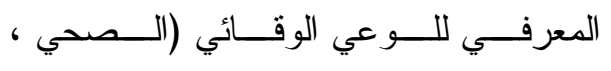
متوسط رثب درجات المجموعتين الضابطة

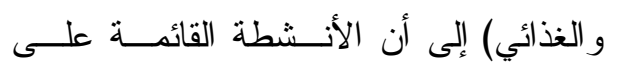

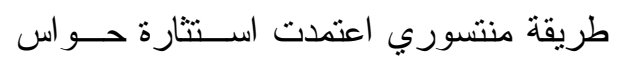
و التجريبية في البُعد الأمنــي إلــى أن: مــن

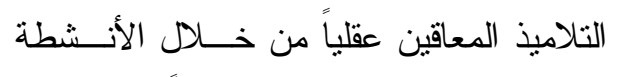

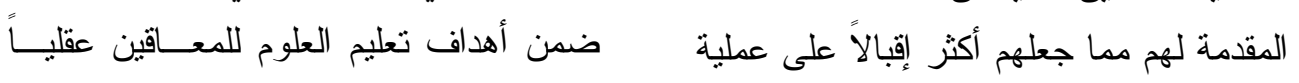

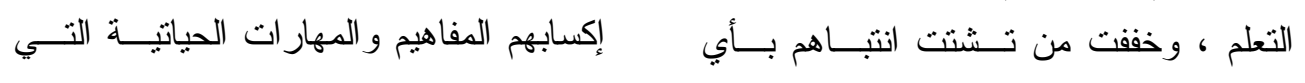


ثانياً: النتائج المتعلقة بالسؤال الثاني: للإجابة عن السؤال الثاني من أســئلة

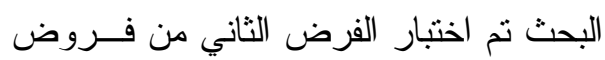

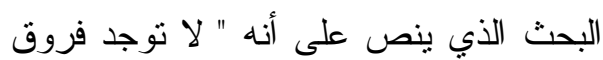

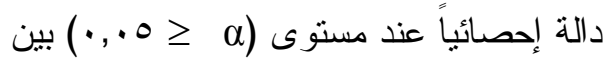

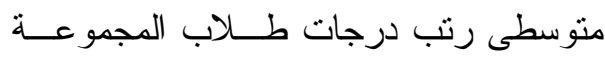
التجريبية و المجموعة الضابطة فى الجانــب درب السلوكي لمقياس الوعي الوقائي بعدياً"

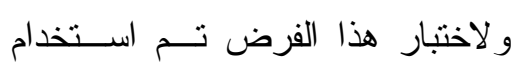

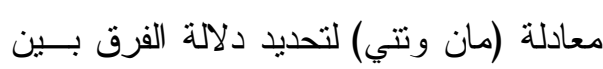

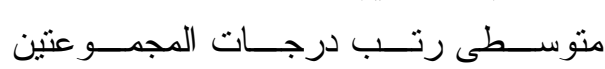

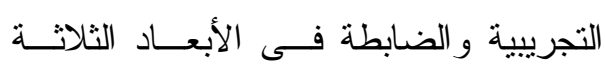
(الصحي، الغذائي و الأمني) للجانب السلوكي الإني

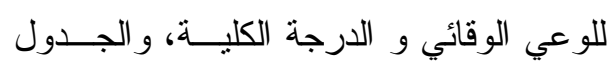

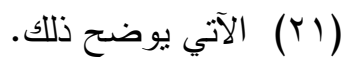

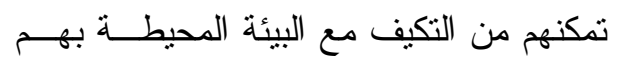

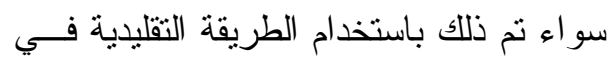

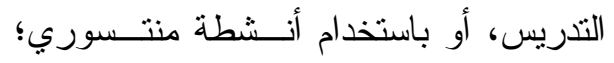

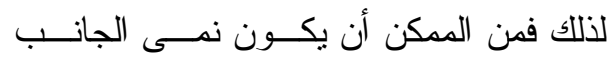

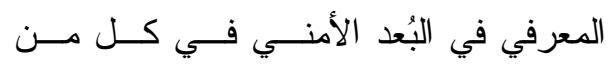

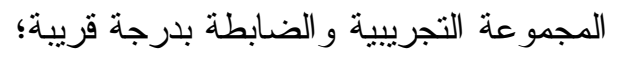

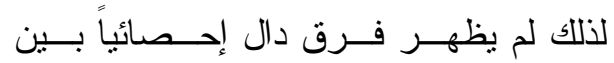
المجموعة الضابطة و المجموعة التجريبة في لهي

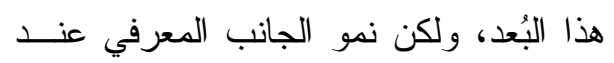

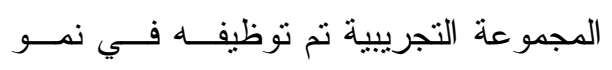
الجانب السلوكي و الوجداني، لذلك كان هناك

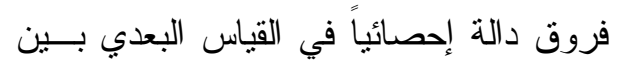

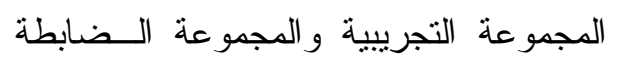

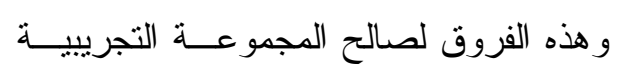

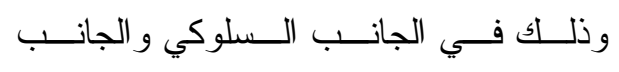
الوجداني .آخري.

جدول (Y)

قيمة " U " ودلالتها الإحصائية للفروق بين رتب درجات المجموعتين التجريبية و الضابطة فى أبعاد الجانب السلوكي و الارجة الكلية بعدياً

\begin{tabular}{|c|c|c|c|c|c|c|c|}
\hline الإحصائية & مستوى الدلالة & قيمة " “ " & مجموع الرتب & متوسط الرتب & $\dot{0}$ & المجموعة & الأبعاد \\
\hline \multirow[t]{2}{*}{ د د الة } & $\cdot, \ldots r$ & $1, T, 0$ & $T V, 0$. & $7, \vee 0$ & 1. & ض ض & صحي \\
\hline & & & $1 \leq r, 0$. & $1 \varepsilon, Y_{0}$ & 1. & ت & \\
\hline \multirow[t]{2}{*}{ د دالة } & $\cdot, \cdots \leq$ & $1 \leq$ & $79, \ldots$ & 7,9 . & 1. & ض ض & غذائي \\
\hline & & & $1 \leq 1, \ldots$ & $1 \leq, 1$. & 1. & $ت$ & \\
\hline \multirow[t]{2}{*}{ د د الة } & $\cdot, \cdots 1$ & 9 & $7 \varepsilon, \ldots$ & $7, \varepsilon$. & 1. & ض ض & أمني \\
\hline & & & $1 \leq 7, \ldots$ & $1 \leq, 7$. & 1. & $ت$ & \\
\hline \multirow[t]{2}{*}{ 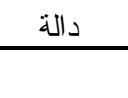 } & $\cdot, \ldots 1$ & - & $00, \ldots$ & 0,0 . & 1. & ض & درجة كلية \\
\hline & & & $100, \ldots$ & $10,0$. & 1. & ت & \\
\hline
\end{tabular}


الجانب السلوكي لمقياس الوعي الوقائي بعدياً

لصالح المجموعة التجريبية"

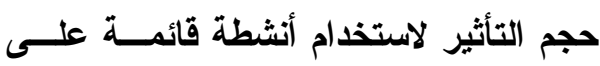

مبادئ منتسوري

لتحديد حجم التأثير لاستخدام أنسـشة مُشة

قائمة على مبادئ منتسوري قي تتمية الجانب

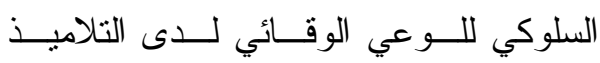

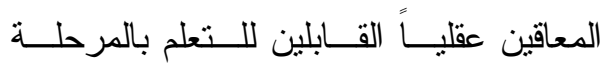

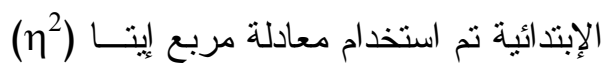

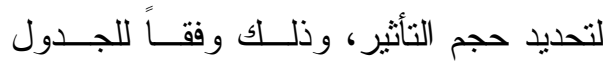

الآتي :
يتضح من الجدول السابق أن جميــع

قيم " U " دالة عند مستوى (0. . • ) فى أبعاد

الجانب السلوكي (الصحي و الغذائي و الأمني)

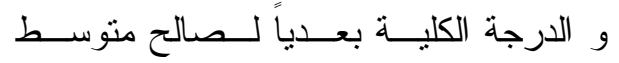

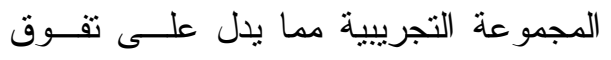

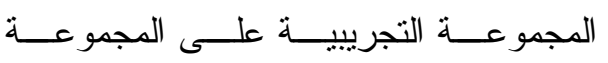
الضابطة فى هذا الجانب. ومن ثم تم رفض الفــرض الثــاني،

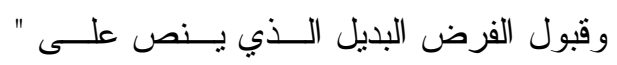

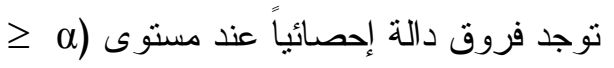

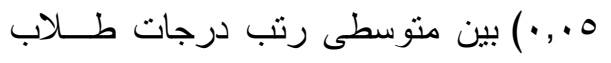
المجموعة التجريبية و المجمو عة الضابطة فى رنى دنى جدول (Yr)

حجم تأثير أنشطة منتسوري فى تنمية الجاتب السلوكي

\begin{tabular}{|c|c|c|c|}
\hline حجم التأثير & $\eta^{2}$ & " Z " " & الأبعاد \\
\hline كبير & . & $r, 90$ & صدي \\
\hline كبير & • & $r, 101$ & غذائي \\
\hline كبير & $\cdot, V Y$ & $r, r)$ & أمني \\
\hline كبير & דו人, . & $r, 104$ & درجة كلية \\
\hline
\end{tabular}

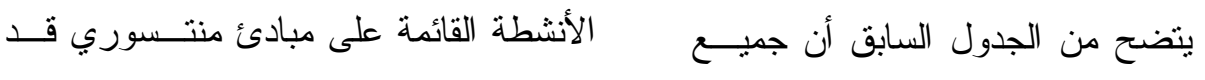
اسهمت فى التباين الكلي الحادث في ملى الجانب

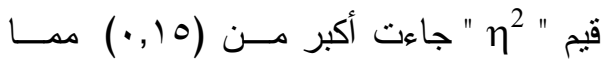

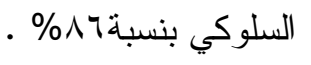

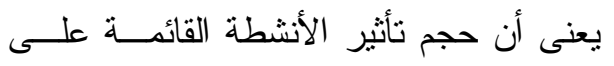

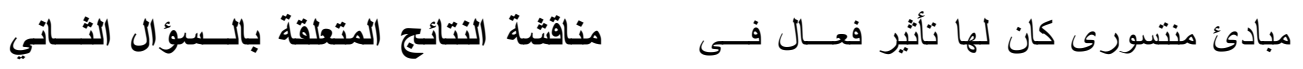

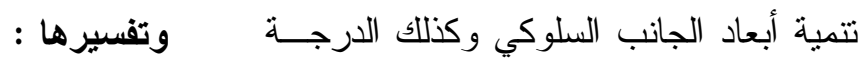
قد ترجع هذه النتائج إلى أن الأنشطة

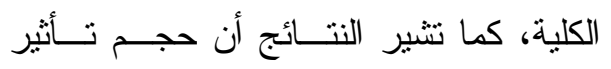

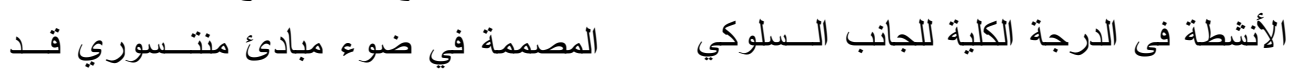

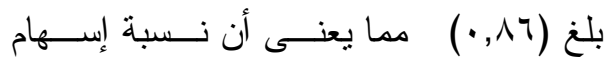


الذي ينص على أنه " لا توجد فــروق دالـــة

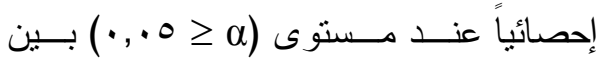

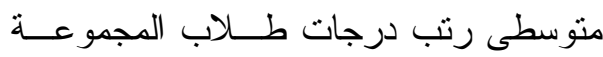

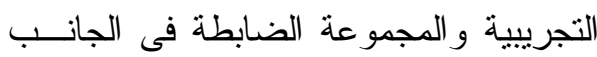
الوجداني لمقياس الوعي الوقائي بعدياً" و لاختبار هذا الفرض تـم اســتخدام معادلة (مان وتتي) لتحديد دلالة الفرق بـين لـين

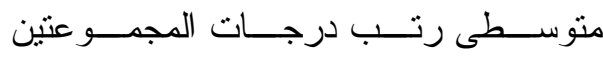
التجريبية و الضابطة فـى الأبعــاد الثلاتـــة (الصحي، الغذائي و الأمني) للجانب الوجداني

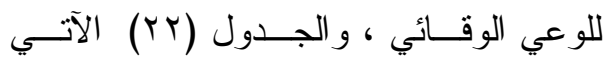

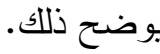

أسهمت في توفير بيئة تعليمية تفاعلية نشطة

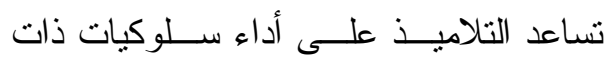

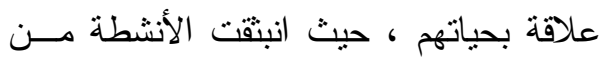

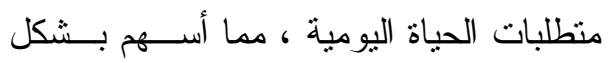

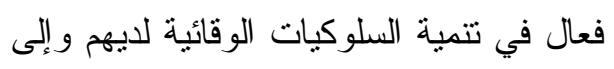

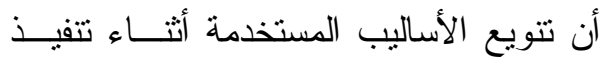

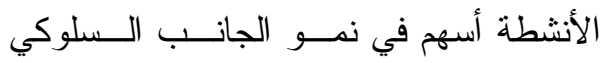

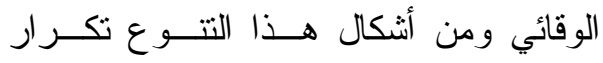

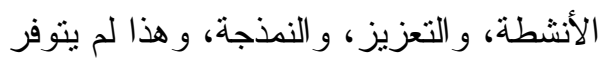
للمجموعة الضابطة . ثالثاً: النتائج المتعلقة بالسؤال الثالث:

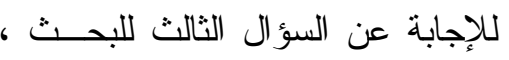
نم اختبار الفرض الثالث من فروض البحــــ

\section{جلول (Yr)}

قيمة " U " ودلالتها الإحصائية للفروق بين رتب درجات المجموعتين التجريبية والضابطة فى أبعاد الجانب الوجداني بعدياً

\begin{tabular}{|c|c|c|c|c|c|c|c|}
\hline الإحصائية & مستوى الدلالة & قيمة " "، U & مجموع الرتب & متوسط الرتب & ن & المجموعة & الأبعاد \\
\hline \multirow[t]{2}{*}{ دالة } & $\cdot, \cdot, 1$ & $r, 0$ & ON,O. & 0,10 & 1. & ض & صحي \\
\hline & & & $101,0$. & 10,10 & 1. & ت & \\
\hline \multirow[t]{2}{*}{ دالة } & $\cdot, \cdot, 1$ & r & $0 \wedge, .$. & $0, \wedge$ & 1. & ض & غذائي \\
\hline & & & lor,.. & $10, r$. & 1. & $ت$ & \\
\hline \multirow[t]{2}{*}{ د د الة } & $\cdot, \ldots)$ & . & $\infty 0, \ldots$ & $0,0$. & 1. & ض & أمنى \\
\hline & & & $100, \ldots$ & $10,0$. & 1. & $ت$ & \\
\hline \multirow[t]{2}{*}{ دالة } & $\cdot, \ldots 1$ & . & $00, \ldots$ & $0,0$. & 1. & ض ض & درجة كلية \\
\hline & & & $100, \ldots$ & $10,0$. & 1. & ت & \\
\hline
\end{tabular}


الجانب الوجداني لمقياس الـــوعي الوقــائي بعدياً لصالح المجموعة التجريبية "

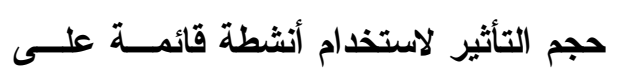
مبادئ منتسوري

لتحديد حجم التأثير لاستخدام أنسشطة قائمة على مبادئ منتسوري قي تتمية أبعاد الجانب الوجداني للوعي الوقائي لدى التلاميذ

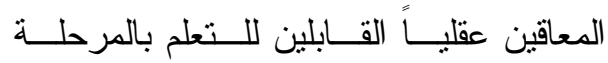

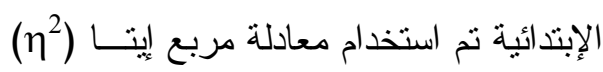

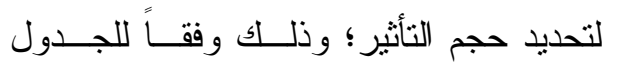
الآتي:

يتضح من الجدول السابق أن جميـع قيم " U " دالة عند مستوى (0. . • ) في أبعاد

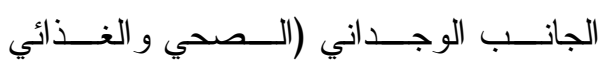

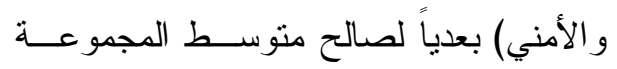

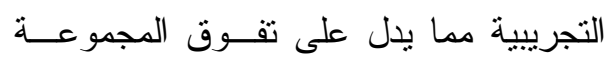

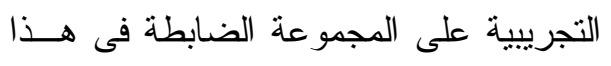
الجانب. ومن ثم تم رفض الفــرض الثالـــث،

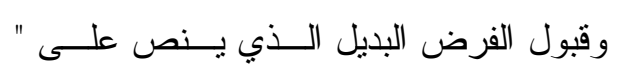

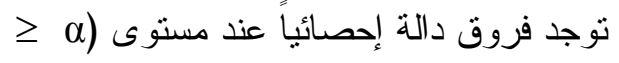

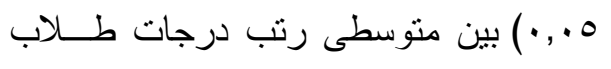
المجمو عة التجريبية والمجمو عة الضابطة فى دلى درسيط جدول (rr)

\begin{tabular}{|c|c|c|c|}
\hline حجم التأثير & $\eta^{2}$ & قيمة " Z " & الأبعاد \\
\hline كبير & $\cdot, \times 9$ & r,ort & صحي \\
\hline كبير & $\cdot, \wedge$. & r,OVT & غذائي \\
\hline كبير & $\cdot, 10$ & r,vav & أمني \\
\hline كبير & $\cdot, 10$ & r,YAo & لـرجة كلية \\
\hline
\end{tabular}

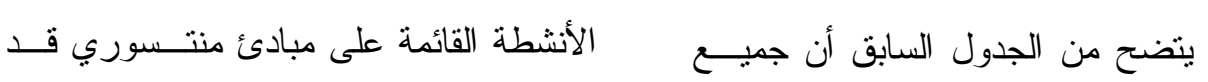

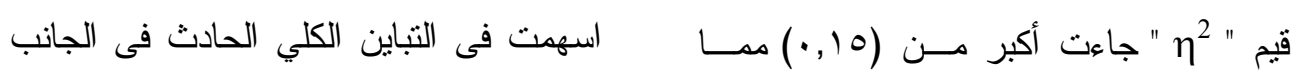

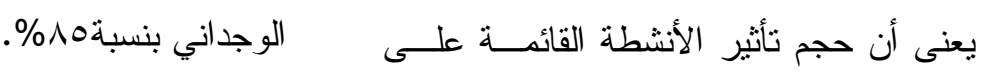

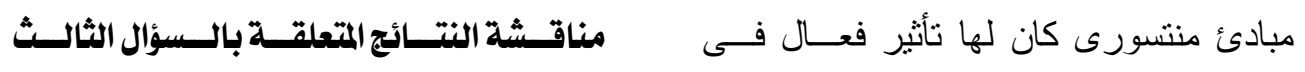

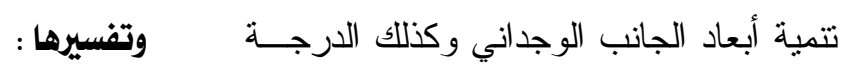

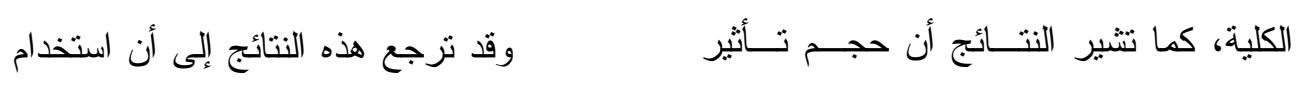

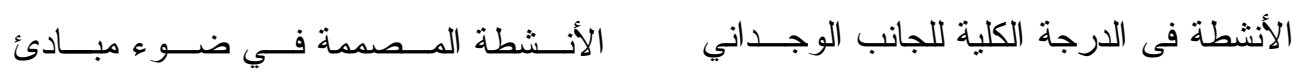

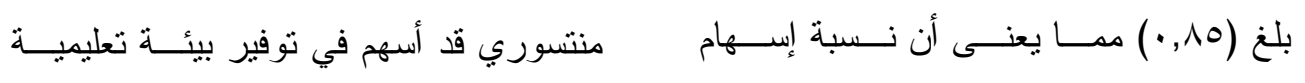


عين شمس، العـددمب، ص صالوس-

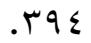

r. أبـــو الحــسن، أحمـــــــــلاح الــدين

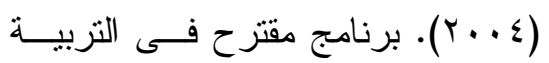

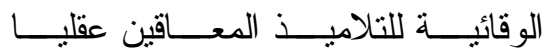

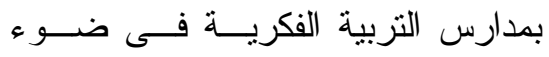
متطلبات إعدادهم المهنى، مجلة الإرشاد النفسى، مركز الإرشاد النفسى بجامعــة

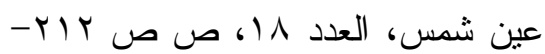
.410

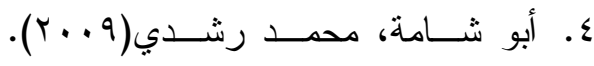
تضمين المفاهيم العلميـــة ذات الــصلة بالتزربية الجنسية فــى منــاهج العلـــوم

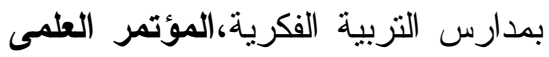
الثالث عثر التربية العلمية- التربيــة العلمية المعلم و المنهج و الكتــاب دعــوة للمر اجعة، الجمعية المــصرية للتربيــة ولهـ

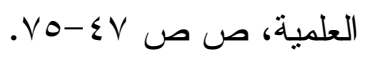

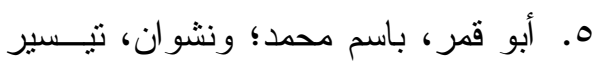

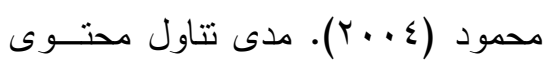

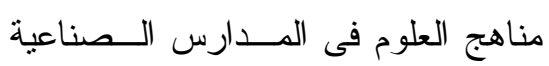

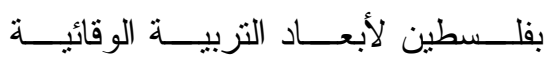

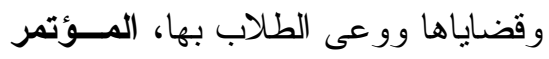

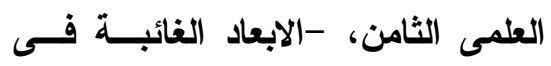
مناهج العلوم بالوطن العربى-، الجمعية

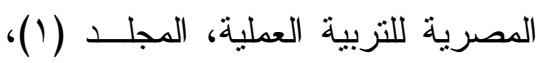

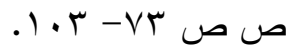

آمنة مثيرة لاهتمام التلميذ المعساق عقليـاً ، وتتمركز حوله بشكل يتتاسب مـــع قدراتــه

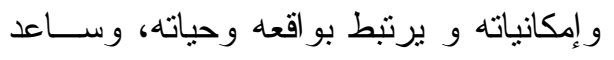
أيضاً في ذللك تقديم التعزيز المناسب له وأثناء ممارسة الأنشطة المنتوعة المرتبطة بالوعي

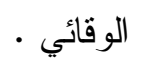
بالإضـافة الى ذلك ممارسة الأنـشطة في جو نفسي آمن يخلو فيها الموقف التعليمي داخل غرفة الصف مــن الخــوف و التــوتر و إثناعة جو من المحبة والأُلفة مع التلاميذ قد

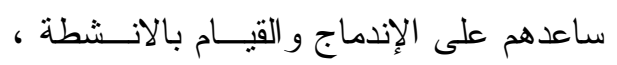

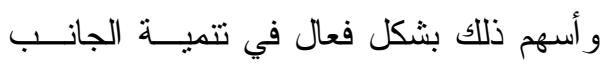

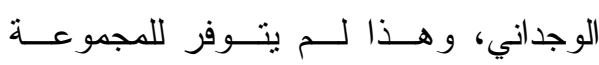

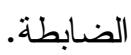

\section{قائمة المراجع}

\section{أولاً: المراجع العربية أمراية}

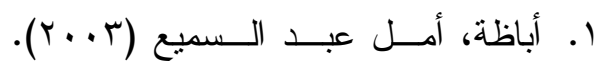
اضطرابات التواصل وعلاجها، القاهرة، مكتبة الانجلوة المصرية.

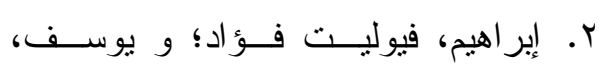

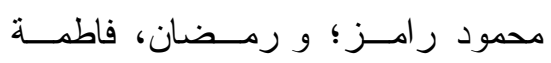

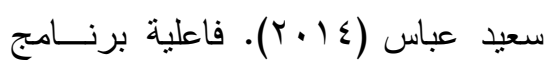
قائم على أنشطة منتيـسورى لتحســين التوافق النفسى لاى عينة من الأطفــال

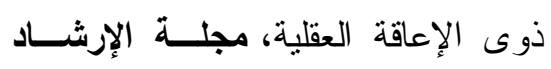
النفسى، مركز الإرشاد النفسى، جامعة الإعه الإنها 


$$
\begin{aligned}
& \text { طــــرق التــــريس و الاســـتر اتيجيات، } \\
& \text { القاهرة، دار الفكر العربي. }
\end{aligned}
$$

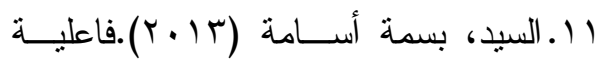

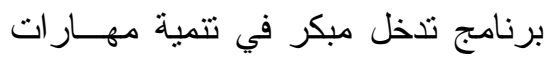

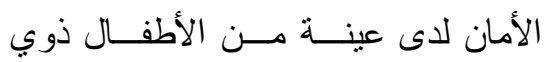

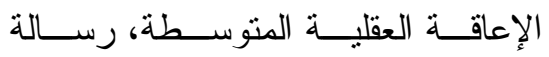

$$
\begin{aligned}
& \text { ماجستير غير منشورة ، كلية التربيــة ، } \\
& \text { جامعة عين شمس. } \\
& \text { Y I.صبري، ماهر اسماعيل؛ ومحمد، أسامة }
\end{aligned}
$$

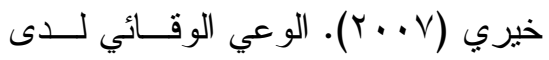

$$
\begin{aligned}
& \text { طلاب المــدارس الثانويــة الــصناعية } \\
& \text { و علاقته بممارستهم لبعض الـسلوكيات }
\end{aligned}
$$

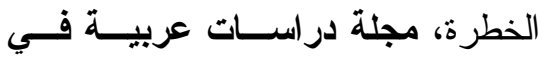

$$
\begin{aligned}
& \text { التربية وعلم النفس، المجلد ا، العدد؟، }
\end{aligned}
$$

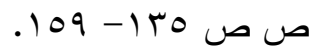

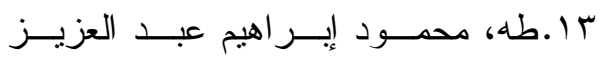

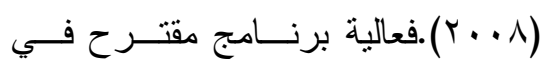

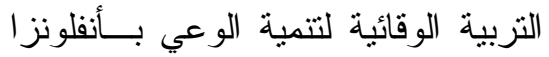

$$
\begin{aligned}
& \text { الطيورلدى طلاب المـــارس الثانويـــة } \\
& \text { الزر اعية، مجلة دراسات عربيــة فـــي }
\end{aligned}
$$

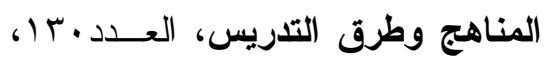

$$
\begin{aligned}
& \text { ص ص }
\end{aligned}
$$

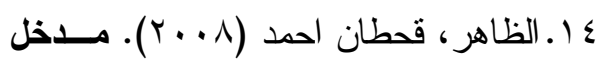

$$
\begin{aligned}
& \text { الى التربية الخاصة، طب، عمــان، دار }
\end{aligned}
$$

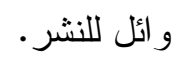

$$
\begin{aligned}
& 0 \\
& \text { التلاميذ المعاقين عقليا القـابلين للــتعلم }
\end{aligned}
$$


عقلياً القابلين للتعلم، رسالة ماجـستير، كلية التربية، جامعة عين شمس.

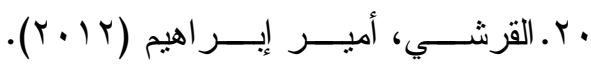
التدريس لذوى الاحتياجات الخاصة بين التصميم والتنفيذ، القاهرة، عالم الكتب.

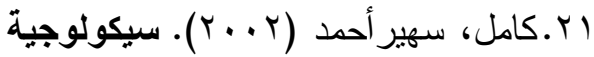
الأطفــال ذوى الاحتياجـــات الخاصـــة، الإسكندرية، مركز الإسكندرية للكتاب.

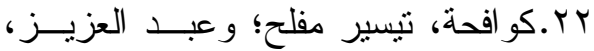
عمر فواز (· ( • (r). مقدمة في التربية الخاصة، طع،عمان، دار المسيرة للنشر

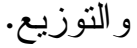

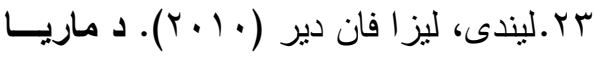
منتسوي في البيث العربــي، القـاهرة، مكتبة دار الكلمة.

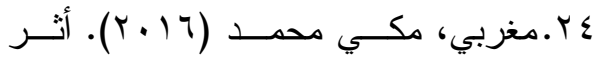
جداول الأنثطة المصورة فــي تتميــة سلوكيات التربية الأمانية لدى التاميــذ القابلين للتعلم بمنطقة القـــيم، مجلــة رسالة الخليج العربي، السعودية، المجلد

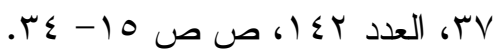
O.Y. ميخائيل، إملى صـادق؛ و أمين، ســهى

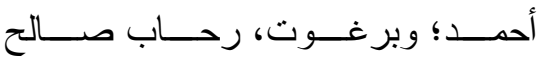

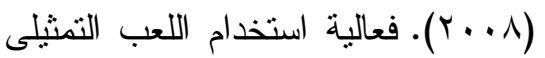
فى تتمية مهــار ات الأمـــان للأطفــال

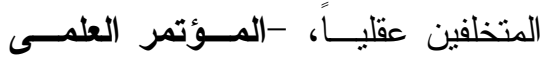
الاولى نحو صناعة آمنة للطقل، كليـة
ببعض السلوكيات الوقائية ومدى تتــاول كتب العلوم لها، مجلة التربية العلمية، الجمعية المــصرية للتزبيــة العمليــة،

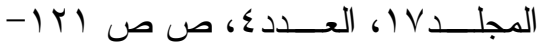
.100

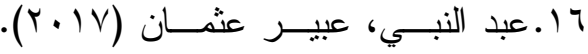
دراسة مقارنة بين برنامج المنتـسوري وبرنامج البورناج في تتمية المهــار ات الاجتماعية لدى الأطفال المعاقين عقلياً مجلة البحث العلمي في التربية، كليـة البنات للآداب و العلوم و التزبية، جامعــة عين شمس، المجلد 7، عــدد 1 (، ص ص ص

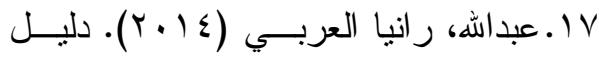
الو الدين لتتمية بعض مهـــار ات الـــوعي الأمني لأطفالهم المعاقين عقليـاً قـابلي التعلم، مجلة البحث العلمي في التربية،

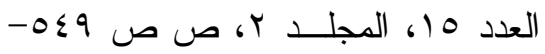
$.0 \mathrm{~V}$.

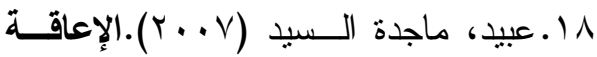
العقلية، طץ، عمان، دار صفاء للنـشر

$$
\text { و التوزيع. }
$$

9 1 . غريب، سامي صلاح محمـد (T (Y) .

فاعليـــة برنــــامج قــائم علـــى طريقــــة

منتسورى لتحــين مهـــار ات الـسلوك التكيفى لدى عينة من الأطفال المعــاقين 
Curriculum and Provided رياض الأطفال، جامعسـة الإســكندرية،

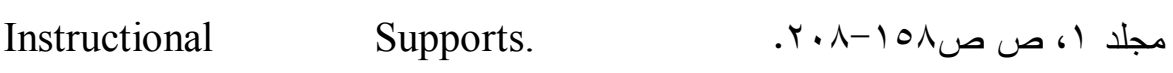

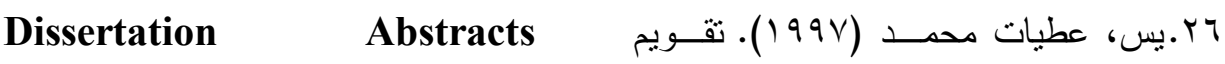

International Section A: مناهج المعاقين عقلياً في ضوء منطلبات

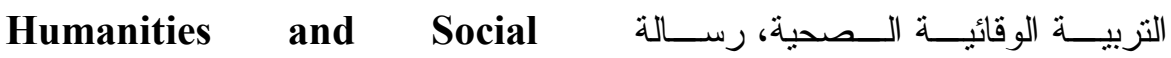

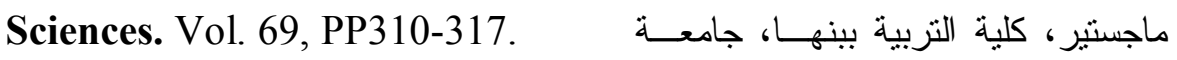

30. Lefort, S. et al., (2006). Social الز قازيق.

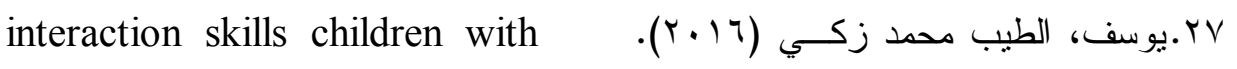
Autism Ascript fading الية برنامج محوسب لتتمية مهـار

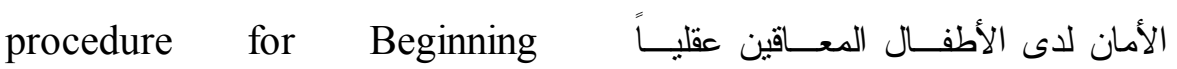

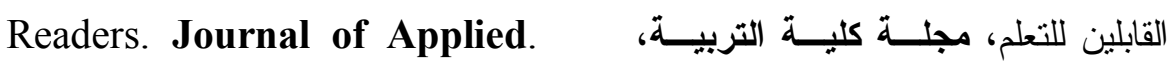
Analysis. Vol. 31, pp. 191-202.

31. Lillard. S. (2011). Mindfulness

Practices in Education:

Montessori's Approach.

Mindfulness. Vol. 2. pp.78-85.

32. Lin. Li-Chan (2009). Using Acupressure and Montessori Based Activities to Decrease Agitation for Residents with Dementia: A Cross-Over Trial. The American Geriatrics Society, Vol. 57. PP. 10221029.

33. Moghni.

H. (2010):

Relationship between

Perceived Montessori

$$
.191-101
$$

$$
\text { ثانياً: المراجع الأجنبية }
$$

28. Claire. A (2006). Games that work. Missing Computer Games to teach AlcoholAffected Children about Fire and Street the Southeas Peramanets Medical Group. Journal of Development Disabilities. Vol (28), p.518.

29. Kim, D. (2009). Access to the General Early Childhood Curriculum: An Investigation of Kansas Participation in the Montessori Early Childhood 
Classroom, Educational theory, Vol, 54, No, 3.

35. Wilcock. A. (2010):

Montessori Based Activities for Persons with Dementia: Effects on Engagement and Sensory Development. Philadelphia, Open University Press.
Characteristics with Parent's Satisfaction, European Journal of Social Sciences, Vol, 16.No.3.

34. Soba, N. W. (2011). Challenging the gaze: the subject of attention and Montessori demonstration 